\title{
A review of anaerobic digestion systems for biodegradable waste: Configurations, operating parameters, and current trends
}

\author{
Dinh Pham Van ${ }^{1 \dagger}$, Takeshi Fujiwara ${ }^{1}$, Bach Leu Tho ${ }^{2}$, Pham Phu Song Toan ${ }^{1,3}$, Giang Hoang Minh ${ }^{2}$ \\ 1Okayama University, 3-1-1 Tsushima, Kita Ward, Okayama 700-8530, Japan \\ ${ }^{2}$ National University of Civil Engineering, 55 Giai Phong Road, Hai Ba Trung District, Ha Noi, Vietnam \\ ${ }^{3}$ The University of Da Nang - University of Technology and Education, 48 Cao Thang, Hai Chau District, Da Nang City, Vietnam
}

\begin{abstract}
With benefits to the human health, environment, economy, and energy, anaerobic digestion (AD) systems have attracted remarkable attention within the scientific community. Anaerobic digestion system is created from (bio)reactors to perform a series of bi-metabolism steps including hydrolysis/acidogenesis, acetogenesis, and methanogenesis. By considering the physical separation of the digestion steps above, AD systems can be classified into single-stage (all digestion steps in one reactor) and multi-stage (digestion steps in various reactors). Operation of the $\mathrm{AD}$ systems does not only depend on the type of digestion system but also relies on the interaction among growth factors (temperature, $\mathrm{pH}$, and nutrients), the type of reactor, and operating parameters (retention time, organic loading rate). However, these interactions were often reviewed inadequately for the single-stage digestion systems. Therefore, this paper aims to provide a comprehensive review of both single-stage and multi-stage systems as well as the influence of the growth factors, operating conditions, and the type of reactor on them. From those points, the advantages, disadvantages, and application range of each system are well understood.
\end{abstract}

Keywords: Anaerobic digester, Anaerobic digestion systems, Single-stage, Solid waste treatment, Three-stage, Two-stage

\section{Introduction}

Solid waste generation is an inevitable consequence of human activities and its rapid increase in recent years has caused significant problems that humankind has to deal with. In 2010, nearly 1.3 billion metric tons of municipal solid waste (MSW) were produced worldwide, and the annual generation is estimated to increase up to 2.2 billion metric tons by 2025 [1, 2]. The organic fraction of MSW (OFMSW) was often reported around 50-60\% of total MSW, which had been cast off in landfills for many years [2-5]. According to Hoornweg and Bhada-Tata [1], an annual amount of 250.05 million tons MSW was dumped into landfills in high-income countries; that of low-income and middle-income countries were 2.67 and 157.1 million tons, respectively. Besides OFMSW, major sources of biodegradable waste also originate from agriculture (animal manures, energy crops, algal biomass, harvest remains), food industry (food/beverage processing, dairy, starch, sugar, pulp/paper, etc.), and sewage sludge [6, 7]. Landfilling bio-degradable waste leads to various issues that threaten the environment and public health $[1,8]$. Also, the fact that the world population continues to grow together with the progress of human civilization leads to the increase of global energy demand. The traditional energy sources such as fossil fuel are exhausting, and nuclear energy is a potential risk to the environment and human health [9]. Thus, the increasing energy demand is becoming a global challenge, and this has promoted the interest in search of alternative energy sources. Meanwhile, biodegradable waste can be converted to methane gas (renewable energy source) by using anaerobic digestion (AD) systems. Therefore, with benefits to the human health, environment, economy, and energy conservation, the $\mathrm{AD}$ systems have attracted remarkable attention within the scientific community $[10,11]$

The $\mathrm{AD}$ systems are constituted from reactors to perform a series of bi-metabolism steps including hydrolysis/acidogenesis,
This is an Open Access article distributed under the terms of the Creative Commons Attribution Non-Commercial License (http://creativecommons.org/licenses/by-nc/3.0/) which permits unrestricted non-commercial use, distribution, and reproduction in any medium, provided the original work is properly cited.

Copyright (C) 2020 Korean Society of Environmental Engineers
Received September 20, 2018 Accepted January 30, 2019

${ }^{\dagger}$ Corresponding author

Email: dinh88.nuce@gmail.com

Tel: +81-86-251-8994 Fax: +81-86-251-8994

ORCID: 0000-0003-1867-0478 
acetogenesis, and methanogenesis [11-13]. By considering the physical separation of the digestion steps in various reactors, the $\mathrm{AD}$ digestion systems include single-stage, two-stage, and three-stage. In which, reactors are the place where growth factors (temperature (T), $\mathrm{pH}$, nutrients) and operating parameters (retention time (RT) and organic loading rate (OLR)) are controlled to allow one or several digestion steps occur [14, 15]. The growth factors affect the living conditions of anaerobes and determine the success or failure of the reactors [11]. Meanwhile, the RT determines the contact time between microorganism and substrate so that it is long enough to complete the transformation. A too long RT will lead to such a big reactor that will increase investment and operating costs. The OLR determines a measure of the amount of daily organic matter treated by a certain volume of the reactor. Both RT and OLR rely on the growth factors and the type of reactor. So the performance of the $\mathrm{AD}$ systems is determined by the complex relationships among the growth factors, the operating parameters, system type, type of reactor, and also coordination of reactors in the system. These relationships were often reviewed inadequately in the single-stage digestion system [6, 11, 12]. Meanwhile, for the multi-stage digestion systems, the information is still limited. Demirel and Yenigün [16] are two of few authors who did a review on the operation of the two-stage digestion system. However, they only investigated one configuration of the continuous stirred tank reactor (CSTR) for hydrolysis/acidogenesis and the upflow anaerobic sludge blanket (UASB) reactor for the methanogenesis. Moreover, the three-stage digestion system has limited information. So far there have been no studies providing a systematic and full review of the $\mathrm{AD}$ systems, including the coordination between the functional reactors in a system as well as the operation of each reactor.

This paper aims to provide a comprehensive review of the $\mathrm{AD}$ systems for biodegradable waste including the single-stage, two-stage, and three-stage systems. Each type of them is discussed about classification, configuration, and operation. Moreover, advantages, disadvantages, and application ranges for each system are also evaluated. The factors influencing the $\mathrm{AD}$ systems are identified and discussed based on the existing literature. Therefore, this study is as a guideline for the $\mathrm{AD}$ system design. This paper is organized into five following sections. Section 1 is an introduction. Section 2 presents mechanism of $\mathrm{AD}$ processes and anaerobic reactors which are responsible for the $\mathrm{AD}$ process. In section 3 , the operation of the $\mathrm{AD}$ systems is systematized according to the biological phase separation, and the newest achievements are reviewed within the literature. Section 4 presents the current applications. Finally, section 5 is conclusions and recommendations.

\section{Basics of Anaerobic Digestion}

\subsection{Biochemical Mechanism of Biogas Production}

The anaerobic digestion is a series of bio-metabolism steps including hydrolysis, acidogenesis, acetogenesis, and methanogenesis, respectively [11-13, 17-20] (see Fig. S1). In which, every digestion step has different growth characteristics as presented below.
The first step (hydrolysis, also called solubilisation) breaks down high molecular weight constituents (e.g., lipids, carbohydrate, and protein) into smaller soluble organic matter (e.g., fatty acid, glucose, and amino acid) by exo-enzymes, and is represented by reaction (1) $[15,21]$. The hydrolytic microorganism has ability to strongly resist the environmental fluctuations and the toxins which may be present in the feedstock [22]. They can work in a wide range of $\mathrm{pH}$ (4-11) [23]. However, $\mathrm{pH}$-values in the range of 6-8 were often reported to provide an optimum working condition for hydrolysis [3, 24, 25]. The hydrolysis of lignocellulosic materials is a relatively slow process. Thus, hydrolysis is considered as a rate-limiting process in the digestion of lignocellulose [13, 18, 26]. Fortunately, this issue can be accelerated significantly by using pre-treatment processes including physical, chemical, and biological methods. The details of these methods are presented by Ariunbaatar et al. [27].

$$
\left(C_{6} H_{10} O_{5}\right)_{n}+n H_{2} O \stackrel{\text { Hydrolysis }}{\longrightarrow} n C_{6} H_{12} O_{6}
$$

The second step (acidogenesis) transforms the products of the hydrolytic process into volatile fatty acids (VFAs) such as propionic acid, butyric acid, acetic acid and ethanol by the action of the acidogenic bacteria [28-30]. They have characteristics of strong and fast growth with a minimum doubling time of $30 \mathrm{~min}$ [31]. Acidogenesis can be described by Eq. (2)-(5) [15, 18, 21, 26]. The pH-conditions significantly influence VFA products. By stepwise shifting $\mathrm{pH}$ from 4 to 8 , the main products changed from butyric and acetic acids to acetic and propionic acids [32, 33]. Moreover, the VFAs formation was strongly inhibited with $\mathrm{pH}$ below 4.0 [34]. The $\mathrm{pH}$ in the range of 5.5-6.5 was often reported as the optimal range [11].

$$
\begin{gathered}
n \mathrm{C}_{6} \mathrm{H}_{12} \mathrm{O}_{6} \stackrel{\text { Acid forming bacteria }}{\longrightarrow} 3 \mathrm{nCH}_{3} \mathrm{COOH} \\
\mathrm{C}_{6} \mathrm{H}_{12} \mathrm{O}_{6}+2 \mathrm{H}_{2} \rightarrow 2 \mathrm{CH}_{3} \mathrm{CH}_{2} \mathrm{COO}^{-}+2 \mathrm{H}^{+}+2 \mathrm{H}_{2} \mathrm{O} \\
\mathrm{C}_{6} \mathrm{H}_{12} \mathrm{O}_{6} \rightarrow \mathrm{CH}_{3}\left(\mathrm{CH}_{2}\right)_{2} \mathrm{COO}^{-}+\mathrm{H}^{+}+2 \mathrm{CO}_{2}+2 \mathrm{H}_{2} \\
\mathrm{C}_{6} \mathrm{H}_{12} \mathrm{O}_{6} \rightarrow 2 \mathrm{CH}_{2} \mathrm{CH}_{2} \mathrm{OH}+2 \mathrm{CO}_{2}
\end{gathered}
$$

The third step (acetogenesis) transforms most products of acidogenesis into acetic acid $\left(\mathrm{CH}_{3} \mathrm{COOH}\right)$, hydrogen $\left(\mathrm{H}_{2}\right)$, and carbon dioxide $\left(\mathrm{CO}_{2}\right)$ as shown in Eq. (6)-(9) [14, 15, 18, 35]. The growth kinetic of acetogenesis is slower than which of acidogenesis, with a minimal doubling time in the range of 1.5-4 d [31]. Acetogens are strict anaerobes, the present of oxidants like oxygen or nitrate is toxic [26], and they work better in acid-weak environment $(\mathrm{pH}$ from 6.0 to 6.2) [31]. Remarkably, high partial pressure of hydrogen product $\left(\geq 10^{-4} \mathrm{~atm}\right.$ ) inhibits Eq. (6) and (7), hence hydrogen product should be released [34, 36]

$$
\begin{gathered}
\mathrm{CH}_{3} \mathrm{CH}_{2} \mathrm{COO}^{-}+2 \mathrm{H}_{2} \mathrm{O} \rightarrow \mathrm{CH}_{3} \mathrm{COO}^{-}+\mathrm{CO}_{2}+3 \mathrm{H}_{2} \\
\mathrm{CH}_{3}\left(\mathrm{CH}_{2}\right)_{2} \mathrm{COO}^{-}+2 \mathrm{H}_{2} \mathrm{O} \rightarrow 2 \mathrm{CH}_{3} \mathrm{COO}^{-}+\mathrm{H}^{+}+2 \mathrm{H}_{2} \\
\mathrm{CH}_{3} \mathrm{CH}_{2} \mathrm{OH}+\mathrm{H}_{2} \mathrm{O} \rightarrow \mathrm{CH}_{3} \mathrm{COO}^{-}+\mathrm{H}^{+}+2 \mathrm{H}_{2}
\end{gathered}
$$




$$
2 \mathrm{CO}_{2}+4 \mathrm{H}_{2} \rightarrow \mathrm{CH}_{3} \mathrm{COO}^{-}+\mathrm{H}^{+}+2 \mathrm{H}_{2} \mathrm{O}
$$

The fourth step (methanogenesis) plays the most important role in generating methane gas by methanogens. There are two basic mechanisms for methane generation including acetoclastic and hydrogenotrophic methanogenesis. The first way, acetotrophic bacteria ferment acetic acid to $\mathrm{CH}_{4}$ and $\mathrm{CO}_{2}$ as Eq. (10) [26, 37]. The second one, hydrogenotrophic methanogens use $\mathrm{CO}_{2}$ and $\mathrm{H}_{2}$ as a food source, as given in Eq. (11) [20, 26, 37]. While the minimum doubling time of hydrogenotrophic bacteria is in the range of 4-12 $\mathrm{h}$, acetotrophic bacteria have a much lower maximum growth rate with doubling times of 2-3 d [31, 37]. Generally, methanogens are extremely sensitive to $\mathrm{pH}$ condition, the presence of oxygen, and other factors such as free ammonia (FAN), $\mathrm{H}_{2} \mathrm{~S}$, and VFAs [15]. They cannot work at $\mathrm{pH}$ condition lower than 6.2, even die in the $\mathrm{pH}$ condition under $6.0[15,18]$, and can be inhibited by releasing free ammonia (FAN) when $\mathrm{pH}$-value is over $>7.8$ [31]. The optimal $\mathrm{pH}$-value was often reported at neutral environment (7.0-7.2) [11, 18, 38, 39]. Methanogenic process lost stable stage when FAN concentration reached 0.6-0.69 g/L [40, 41], reduced $50 \%$ performance when FAN concentration was $1.45 \mathrm{~g} / \mathrm{L}$ [42], and failed by FAN concentration of 1.7-1.8 g/L [43]. The optimum concentrations of sulfur for the growth of methanogens were reported in the literature to vary from 16 to $160 \mathrm{mg}-\mathrm{S} / \mathrm{L}$ [44]. The methanogenesis was often stable with a low VFA concentration $(<200 \mathrm{mg} / \mathrm{L})$, and inhibition occurred when acetate concentration exceeded $3 \mathrm{~g} / \mathrm{L}$ [36]. The oscillation of temperature in the reactor should be as small as possible, that is, $<1^{\circ} \mathrm{C} / \mathrm{d}$ for thermophiles and $2-3^{\circ} \mathrm{C} / \mathrm{d}$ for mesophiles [15].

$$
\begin{gathered}
\mathrm{CH}_{3} \mathrm{COOH} \stackrel{\text { acetociastic bacteria }}{\longrightarrow} \mathrm{CH}_{4}+\mathrm{CO}_{2} \\
\mathrm{CO}_{2}+4 \mathrm{H}_{2} \stackrel{\text { hydrogenotrophic bacteria }}{\longrightarrow} \mathrm{CH}_{4}+2 \mathrm{H}_{2} \mathrm{O}
\end{gathered}
$$

\subsection{Anaerobic Reactors}

Anaerobic reactor (digester) is considered as the heart of digestion systems, which encourages anaerobic microorganisms to thrive inside for responding to the digestion steps. While the success of the digester depends very much on $\mathrm{pH}$ condition as described in section 2.1, its digestion rate is significantly dependent on temperature condition. Temperature is not only one of the most important in the selection of microbial group inside reactors, but it also influences the state of substrates such as the solubility, metabolic rate, and ionization equilibria. According to temperature conditions, there are three microorganism groups including psychrophiles, mesophiles and thermophiles, respectively living in the temperature range of $4-15^{\circ} \mathrm{C}, 20-40^{\circ} \mathrm{C}$ and $45-70^{\circ} \mathrm{C}$ [45]. The influence of temperature on the growth rate of each group is shown in Fig. S2. In general, the increase in temperature has benefits of enhancing reaction rates significantly [17]. However, the mesophiles are less sensitive to environmental changes than the thermophiles, hence operation reactor at thermophilic temperature requires higher technic than mesophilic condition [14, 46].

The anaerobic digesters can be categorized in several different ways, but the main classification can be set between wet and dry types relied on total solid (TS) contents because solid concen- tration has a great impact on the cost, performance, and technique of the $\mathrm{AD}$ process $[47,48]$. Categorization of anaerobic reactors is summarized in Fig. 1(a). The dry digesters have been designed to serve the feedstock having TS $\geq 20 \%$, hence solid concentration within the reactor is also high (TS $\geq 15 \%$ ) [3, 47, 49]. In the dry digester, the substrate particles play the roles of nutrient source and also supporting media. Especially, the microorganisms not only attach to the surface but also penetrate through substrate particles [50]. The dry type can be classified into three groups including the horizontal plug-flow, vertical plug-flow, and non-flow (batch type). The brief descriptions of these digesters are shown in Table S1, and the discussion about them is presented in the next section. The wet digesters are defined to serve the feedstock having TS $\leq 15 \%$ and well known in the wastewater treatment field [5, 51]. They can often be classified based on the growth of bacteria inside including suspended growth and attached growth [52]. In the suspended growth digester, the microorganisms are maintained in suspension within the liquid. Meanwhile, they attach and grow on the surface of supporting media in the attached growth reactor. Detail descriptions of their representatives are shown in Table S2.

The design and operation of the anaerobic reactor are characterized by two parameters including RT and OLR. In which, the $\mathrm{RT}$ is defined as the average time that the substrate maintained in a reactor and quantified by the equation: $\mathrm{RT}=$ reactor volume/daily flow. The RT has to be long enough to ensure the completion of one or several digestion steps that the reactor is in charge. For the wet reactor, the substrate materials are often separated into liquid and solid materials thus the RT is divided into hydraulic RT (HRT) and solid RT (SRT). Meanwhile, the OLR gives a measure of the amount of daily organic matter treated by a certain volume of the reactor and calculated indirectly via RT by equation OLR = Organic-concentration/RT. Both RT and OLR depend on the process parameters that influence the anaerobic bacterial growth such as temperature, $\mathrm{pH}$, and waste characteristics.

\section{Anaerobic Digestion Systems}

The simplest anaerobic digestion system contains one reactor which is responsible for doing all four digestion steps. It is called the single-stage digestion system. However, along with the development of science and biotechnology, scientists have found that each digestion step has different optimal thriving conditions [3, 11, 31]. Therefore, the idea of the physical separation of the digestion steps (multi-stage digestion) has been given the aim to optimize each of them to reach the highest performance of transformation. Currently, the multi-stage digestion systems only include two-stage and three-stage systems. The two-stage system performs hydrolysis and methanogenesis in two different reactors. More complex, the three-stage system performs the hydrolysis, acidogenesis/acetogenesis, and methanogenesis in various reactors. This paper classifies the subcategories of the $\mathrm{AD}$ systems based on type (wet or dry) of reactor employed as shown in Fig. 1(b). 

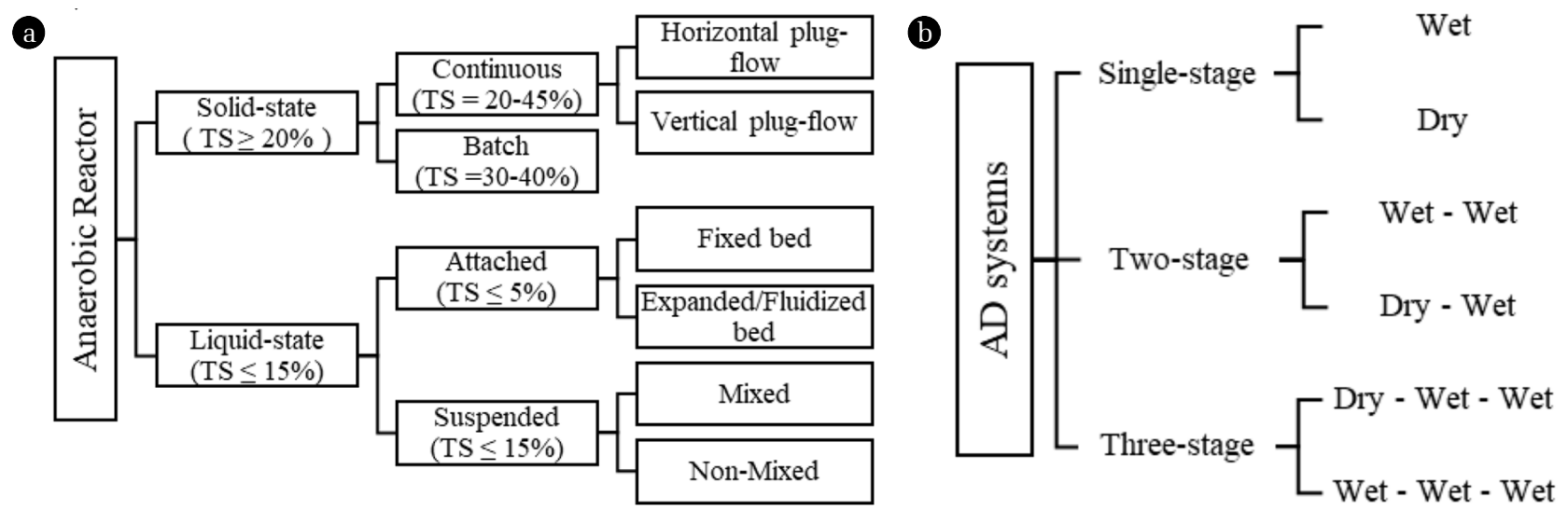

Fig. 1. a) Classification of digesters; b) classification of $A D$ systems.

\subsection{The Single-Stage Systems}

In principle, the environmental conditions are not necessarily optimal for any digestion step, but they satisfy all four steps [18]. However as shown in section 2.1, the range of growth conditions for the methanogen is covered by the other process steps. Moreover, methanogens are the most sensitive to the environment and also have the slowest growth among microorganism consortium. Therefore, the environmental conditions in the single-stage digestion systems should be optimized for methanogenesis. Commonly, the single-stage system operates with some requirements: Carbon to nitrogen $(\mathrm{C} / \mathrm{N})$ of the substrate in the range of $15-30[6,11$, 13]; $\mathrm{pH}$ ranging between 6.8 and 7.4 [6, 11]; HRT $30 \mathrm{~d}$ at mesophilic temperature, $20 \mathrm{~d}$ at thermophilic, and $50 \mathrm{~d}$ at psychrophilic.

\subsubsection{The wet single-stage systems}

They are the single-stage systems employing the wet reactor, and they can be classified into two groups including low-rate (OLR $\left.=0.5-1.6 \mathrm{~kg}-\mathrm{VS} / \mathrm{m}^{3} \cdot \mathrm{d}^{-1}\right)$ and high-rate $\left(\mathrm{OLR}=1.6-4.8 \mathrm{~kg}-\mathrm{VS} / \mathrm{m}^{3} \cdot \mathrm{d}^{-1}\right)$ [31]. A number of studies have shown that they are sensitive to inhibitor such as FAN. According to the study of Duan et al. [41], FAN level $>0.6 \mathrm{mg} / \mathrm{L}$ was the key factor influencing system stability. Nakakubo et al. [42] showed that methane yield was reduced 50\% when FAN concentration was up to $1.45 \mathrm{~g} / \mathrm{L}$. And Yen and Brune [53] reported that the system could fail when FAN increased within to the range of 1.7-1.8 g/L.

\subsubsection{The wet low-rate system}

The wet low-rate system is the oldest and simplest type, has its key characteristics such as long RT (30-60 d), poor mixing process, and non-heating process $[39,54]$. It is a very simple operation, but very low performance; hence the low-rate systems have only been used within household-scale and farm-scale in developing countries such as China, India, and Vietnam [21]. The diagram principle of these systems is shown in Table S2(a). It doesn't matter if it is small or large-scale, there is always a stratification inside reactors with four zones: (i) a scum layer, (ii) a liquid layer (or supernatant), (iii) a layer of digesting solids, and (iv) a layer of digested solids [17, 39]. Among these systems, the household-scale one (Table S2(b)) is also known as floating-dome digester or fixed dome digester. Although it has capacity in the range of $1-8 \mathrm{~m}^{3}$, the $1-3 \mathrm{~m}^{3}$ one is the most commonly used. In this system, the daily feedstock is about $1 / 40-1 / 50$ of the reactor volume [21]. The farm-scale one (lagoon digester or anaerobic pond, see Table S2(c) is operated with an HRT in the range of 30-60 d, SRT of 50-100 d, and TS of the feedstock of 0.5 to $5 \%$ [52].

\subsubsection{The wet high-rate systems}

The wet high-rate systems have been developed from the low-rate digestion for improving performance. The feedstock can be heated and mixed to make a uniform environment, which leads to the fact that the reactor is less volume, more stable and more efficient [54]. The first generation of the wet high-rate systems uses the wet plug flow (WPF) reactor (see Table S2(d)), which is supported by a heat source. This system has been applied the most for manure with solid content in the range of $11-14 \%$ and HRT of 15-20 d [21, 55]. A more complicated reactor called completely mixed reactor (CMR) or continuous stirred tank reactor (CSTR) requires internal mixing activities, see Table S2(e). This system often operates at mesophilic temperature with OLR in the range of 1.5-5 $\mathrm{kg}-\mathrm{VS} / \mathrm{m}^{3} \cdot \mathrm{d}^{-1}$ and RT from $15-20 \mathrm{~d}$ [21]. In the CSTR, the bacteria get washed away together with the effluent out of reactor [21]. Meanwhile, to reach higher OLR, the reactor need a higher concentration of bacteria maintained inside. Therefore, the biomass of the effluent is separated in a settling tank and pumped back to the reactor where the biomass concentration is maintained in the range of $5-10 \%$ VS [21, 34, 36]. It is called anaerobic contact (AC) system as shown in Table S2(f) Waasa, a famous brand name of AC system, is used for treating OFMSW. In Waasa system, fresh materials are mixed with effluent water to attain $10-15 \%$ TS. The OLR could reach $4-8 \mathrm{~kg}-\mathrm{VS} / \mathrm{m}^{3} \cdot \mathrm{d}^{-1}$ with the efficiency of 100-150 $\mathrm{m}^{3}$-biogas/ton-waste and TS reduction of 50-60\% [5].

When the substrate of the feedstock is mainly in the soluble state (or TS $<3-5 \%$ ), the wet reactors with high biomass concentrations such as upflow anaerobic sludge blanket (UASB), expanded granular sludge bed (ESGB), expanded bed (EB), fluidized bed (FB), internal circulation (IC), and anaerobic fixed bed (AFB) can be employed. The principles and application range of these reactors are presented in Table. S2. They are well known in the industrial wastewater treatment sector. In the United States, application allocation of anaerobic technologies in the industrial wastewater treatment 
for period 2002-2007 included 34\% UASB, 33\% IC, 22\% EGSB, $1 \% \mathrm{AFB}$, and $10 \%$ others [37].

\subsubsection{The dry single-stage systems}

The high solid waste can be treated by the wet digestion systems, but it needs to be added a large amount of water. Unfortunately, dilution of the waste stream not only demands higher costs of water and energy consumption but also requires a reactor with higher volume. Moreover, dilution of waste can drag on reducing biogas yield and make more wastewater [47]. Therefore, the dry digesters have been developed to deal with high solid waste (see Table. S1). The main issues with the operation of dry systems compared to which of wet systems are the mixing and pumping of the substrate with high viscosity [51]. Along with the evolution of technologies, these issues gradually reduced. Nowadays Dranco, Valorga, Kompogas, and Biocell are the most commonly applied systems of pilot scale plans in Europe [5, 51]. Generally, the dry systems are stronger than the wet ones because of stability even with ammonia concentration up to $2.5-3 \mathrm{~g} / \mathrm{L}$ and VFAs in the range of $23-24 \mathrm{~g} / \mathrm{L}[3,56]$.

The Dranco system is such a vertical plug-flow digester (see Table. S1(a)). In this system, a part of the digestate is taken back to the mixing pump where it is blended with fresh materials (separated sources, particle size $<4 \mathrm{~cm}$ ) for inoculation with a ratio of 6-8:1. After that, the mixture is introduced into the top of the reactor and moves downward to the conical bottom where a screw conveyor removes the digestate. The rest of digestate is dewatered before being composted. There is no active mixing within the reactor, hence $20-30 \%$ of biogas can be lost because of the incomplete digestion [3]. The system has been proved successful to treat solid wastes with TS ranging from 20 to 50\% [47]. When OFMSW (TS of 30-45\%) is processed in the mesophilic condition with HRT $20 \mathrm{~d}$, VS decreases $55 \%$ and $5-8 \mathrm{~kg}-\mathrm{VS} / \mathrm{m}^{3} . \mathrm{d}^{-1}$ OLR is produced [3, 7]. In the thermophilic temperature with RT $14 \mathrm{~d}$, the amount of OLR could be up to $15 \mathrm{~kg}-\mathrm{VS} / \mathrm{m}^{3} \cdot \mathrm{d}^{-1}$ and $65 \%$ of VS could be destroyed [5]. For digestion of OFMSW, alkali additive is often unnecessary, and $\mathrm{pH}$ inside the reactor is nearly 8. Each ton of waste can produce $120-170 \mathrm{~m}^{3}$-biogas (equivalent to $200 \mathrm{kWh}$ ) and the plant consumes $30-40 \%$ of it and exports the rest [3].

The Kompogas system employs a horizontal plug-flow digester with internal rotors to assist in degassing and homogenizing waste (see Table. S1(b)). The incoming waste stream (particle size < $50 \mathrm{~mm}$ ) is mixed with the liquid of the digestate to attain TS in the range of $23-28 \%$ for the system to flow properly. At higher TS values, the mixture is hard to flow because of too high viscosity while lower TS values lead to accumulating sand and glass inside the reactor [5, 47]. The system often operates in the thermophilic condition $\left(55-60^{\circ} \mathrm{C}\right)$ with HRT of $14-20 \mathrm{~d}$. The digestate is dewatered by using a screw press then the solid part is composted by aeration within 2-3 weeks [3,5]. For one ton of waste, the system can produce $130-150 \mathrm{~m}^{3}$-biogas, $500 \mathrm{~kg}$-compost, and $300 \mathrm{~L}$ liquid fertilizer.

The Valorga system uses a vertical plug-flow reactor (see Table. S1(a)). The feedstock is the mixture of the incoming waste stream (size $<30 \mathrm{~mm}$ ) and the digestate with TS adjusted in the range of $25-30 \%$. If TS concentration is less than $20 \%$, the grit particles will quickly settle down to the bottom and clog the recirculated-gas pores [5]. The system produces about $140 \mathrm{~m}^{3}$-biogas/ton-waste with VS removal rate of $50 \%$ [7]. For the substrate of OFMSW, the $\mathrm{pH}$ inside is often in the range of 7.8-8, hence alkali additive is not required. When $\mathrm{pH}$ drops, the feeding pump should stop until process regulates itself [3]. A part of the biogas product is injected back at the bottom of the reactor with high pressure (5 bar) for mixing purpose and keeping materials suspended [3, 21]. The system is often operated in the mesophilic temperature with RT of 18-23 d and produces biogas yield of 220-270 L/ $/ \mathrm{kg}-\mathrm{VS}$. After digestion, the digestate is composted within 2-3 weeks [5].

The dry-batch digestion system (see Table S1(c)): This system originates to mimic the landfill process. However, unlike natural biodegradation in the landfill, the reaction in the dry-batch system is accelerated by two basic factors. The first one is the continuous recirculation of the leachate. It permits formation of a high humidity environment and diffuseness of the inoculum and the substrates. The second one is that temperature in the systems is controlled at the optimum range. This resulted in many fold higher biogas production rates and lower RT than observed in landfills [49]. The digester is loaded with fresh materials (TS of 30-40\%), discharged, and then filled with a new batch. The digestion time finishes when biogas production ceases. After more than $20 \mathrm{~d}$ digesting at the mesophilic temperature, the digestate is aerated for 1-3 weeks for composting [5, 51]. For each ton of waste, the system produces $90 \mathrm{~kg}$ of biogas $\left(58 \% \mathrm{CH}_{4}\right), 455 \mathrm{~kg}$ wastewater, and $310 \mathrm{~kg}$ of compost [39]. Despite saving 40\% equipment cost compared to continuous-dry systems, the batch-dry systems have much lower applied ratio because they need much more space for construction [5].

\subsubsection{Assessments}

The single-stage digestion systems have a wide application range and can cover the most type of biodegradable waste. The evaluation of the systems based on some technical targets is shown in Table 1; it also includes their advantages and disadvantages. In the single-stage digestion systems, the strong group bacteria (facultative microorganisms) can easily repulse the weak groups (methanogens) when living in the same reactor. Thus, the fluctuations of the load, $\mathrm{pH}$, and solid concentration of the feedstock could harm the stability of the system. If the rate of acid formation is more than the rate of methane formation, it means there is an accumulation of VFAs, the system must be stopped and waited for turning stable status. Therefore, the two-stage system can be considered as an optimal solution to deal with the mentioned issues above.

\subsection{The Two-Stage Systems}

\subsubsection{Configuration of two-stage systems}

The growth characteristics of the hydrolysis/acidogenesis and the methanogenesis are very different. Therefore, the idea for two-stage digestion is given to optimizing every digestion step. In the present, there are two different viewpoints about separating digestion-steps into two reactors. The first perspective supposes that the first tank allows the hydrolysis/acidogenesis to occur, and the second tank optimizes the acetogenesis/methanogenesis [49, 76]. Meanwhile, the second perspective proposes that the acetogenesis 


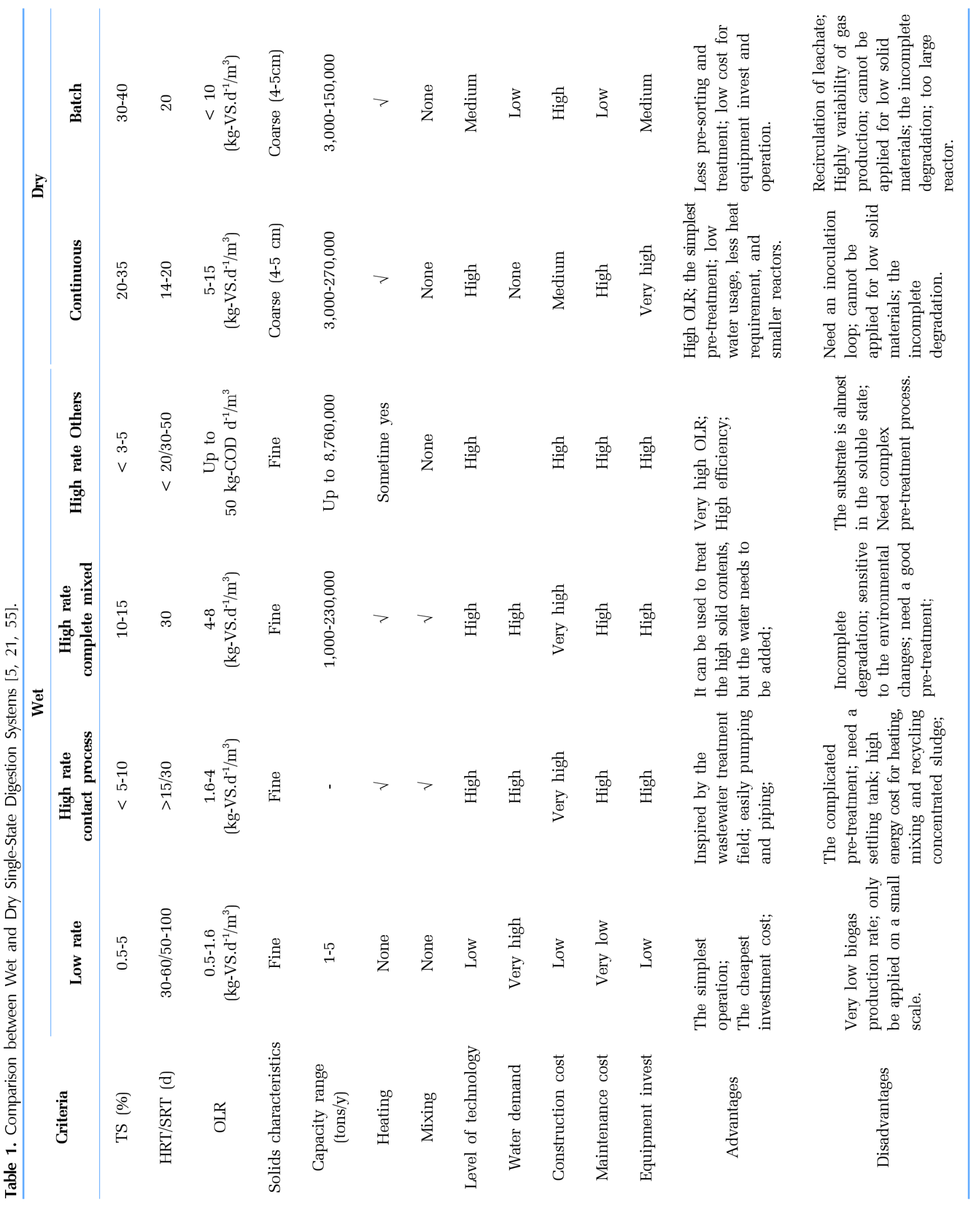




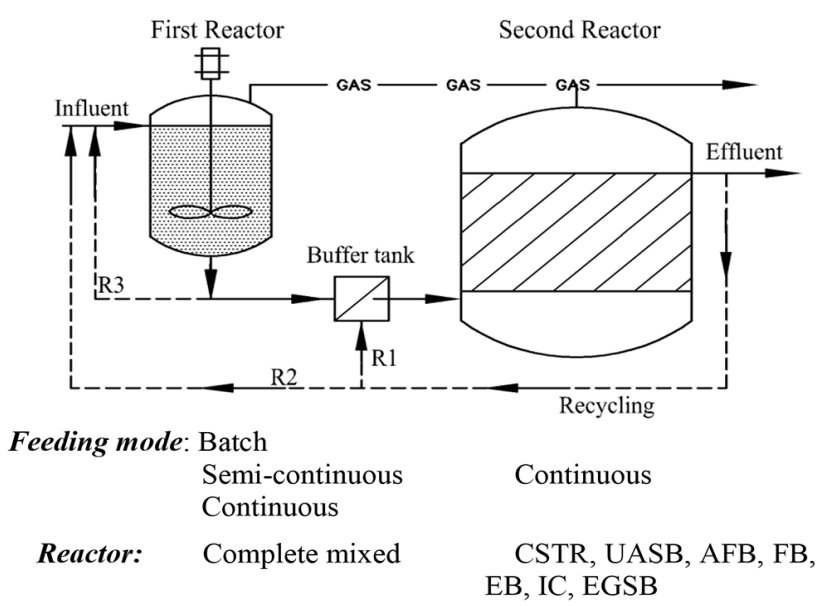

Fig. 2. The configuration of the two-stage digestion system.

should be in the first reactor and the second reactor only optimizes methanogenesis [18, 54]. The second point of view might like to maximize hydrogen product from acetogenesis. However, there are several reasons why this idea is not reasonable. Firstly, hydrogen production from $\mathrm{AD}$ is currently not economically viable because of the high cost required to enrich the hydrogen gas to meet the commercial quality standards [38]. Secondly, as described in section 2.1, methanogens (hydrogen consumer) and acetogens (hydrogen producer) should work in close cooperation. Thirdly, acetogens are also sensitive and strict anaerobes; they should not work together with facultative bacteria (hydrolytic/acidogenic microorganism). In fact, the true separation of the digestion-steps is very difficult to achieve [21], hence the acetogenesis can occur in both reactors but mostly in the second one. Diagram of two-stage systems is shown in Fig. 2.

Because of the different environmental conditions between two reactors, a buffer tank is often set between two reactors as shown in Fig. 2 for many purposes such as removing non-hydrolysable materials, controlling $\mathrm{pH}$, and even controlling the organic concentration [38, 77]. The two-stage system can use one, two, or all three water recirculation loops (R1, R2, and R3, shown in Fig. 2) in case of need. Using these recirculation loops brings many advantages, such as further controlling of $\mathrm{pH}$ (reduction of acidity due to using the high alkalinity effluent from the second reactor); mixing/diluting of the high solid feedstock; and improving activities of bacteria [38, 76]. However, if the inhibitors are accumulated inside reactors and cause the unstable condition of the system due to long time being used, the incoming substrate should be diluted by fresh water. After hydrolysis, the solid content of feedstock decreases significantly. Therefore, the two-stage system may be a dry-wet configuration (high solid in the first digester and low solid in the second digester) or wet-wet configuration (both stages are low solid) [5, 49]. The hydrolysis/acidogenesis usually employs a CSTR [37]. Meanwhile, the methanogenesis uses the wet high-rate reactors including CSTR, UASB, AFB, FB, EB, IC, and EGSB [14, 36].

\subsubsection{The hydrolytic/acidogenic reactor}

The mission of this reactor is to convert the substrate to the VFAs as fast as possible while avoiding being inhibited and overloaded. Therefore, a series of operating conditions including $\mathrm{pH}$, temperature, acid concentration, nutrients, and substrate concentration (TS) must be controlled. For the high-solid waste such as OFMSW, the waste stream should be shredded to reduce particle size $(<$ $15 \mathrm{~mm}$ ) before being fed to the reactor [3]. The hydrolysis/acetogenesis generally proceeds sufficiently fast in the mixing tanks, hence no further reactor has been developed for the hydrolysis/acetogenesis [37]. Among mixing tanks, the CSTR is used the most, the wet plug-flow reactor sometimes [3, 49].

Total solids: Hydrolyzing the high-solids feedstock allows the reactor to operate larger capacity, requires less energy for heating and less water consumption. However, a too high solid content can cause high viscosity of the mixtures, which leads to the fact that insufficient mixing or mixing can be too energy-consuming $[18,78,79]$. Moreover, the increase of solid content (in the range of 5-40\%) causes the increase of inhibitors and insoluble solids content, which leads to the decrease of the hydrolytic conversion rate [79]. Also, a high solid concentration (TS > 15\%) of feedstock requires much longer RT (10-15 d) than usual [18]. Thus, TS of $15-20 \%$ in the feedstock is often considered as the upper limit for hydrolysis/acidogenesis when using the mixed reactor [78].

pH value: Moestedt et al. [80] reported that the $\mathrm{pH}$ below 4.5 led to requiring HRT up to $15 \mathrm{~d}$ in the hydrolytic/acidogenic reactor. Yu and Fang [81] lifted up pH from 4 to 5.5, which resulted solubility and acidification of substrates increased significantly [81]. Whereas under alkaline conditions, Zhang et al. [25] reported that VFAs formation was significantly decreased when $\mathrm{pH}$ increased from 7 to 11 . Deublein and Steinhauser [35] showed that $\mathrm{pH}>10$ caused an irreversible loss of the activity of the microorganisms. The $\mathrm{pH}$ values between 5.5 and 6.5 were often reported as an optimal range and the best $\mathrm{pH}$ values was 6.0 [54, 82-84]. These results are reasonable for each condition of hydrolysis and acidogenesis as presented in section 2.1.

Temperature: Most studies have agreed that the hydrolytic/acidogenic rate is proportional to the increase of temperature [23, 85, 86]. In addition, compared to the mesophilic conditions, the thermophilic regimes have been increased destruction of pathogens which might have a severe impact on reactor and environment [87]. Therefore, thermophilic temperature seems better than mesophilic one. However, Kozuchowska and Evison [88] reported that the mesophilic operations provided a more stable condition than the thermophilic operation in acidification of coffee waste. Komemoto et al. [89] even notified that the solubilization rate of food waste was significantly higher in mesophilic conditions than others. Thus, regarding energy and efficiency, the mesophilic temperature in the range of $35-37^{\circ} \mathrm{C}$ is still preferred to use for the hydrolysis/acidogenesis of organic waste, see Table 3.

Retention time: RT of this reactor depends on not only the environmental conditions but also waste characteristics. For hydrolysis/acidogenesis of the source-sorted OFMSW (TS 8.2\%), Pavan et al. [90] recommended that RT would be safe in the range of 2-3 $\mathrm{d}$ at the mesophilic temperature. At the same temperature above but for food waste, Paudel et al. [91] optimized RTs and reported that one $\mathrm{d}$ was the best. Meanwhile, for agro-industrial wastewater, Dareioti and Kornaros [92] even got the highest efficiency of acidogenesis achieved at lower RT (0.75 d). In general, 


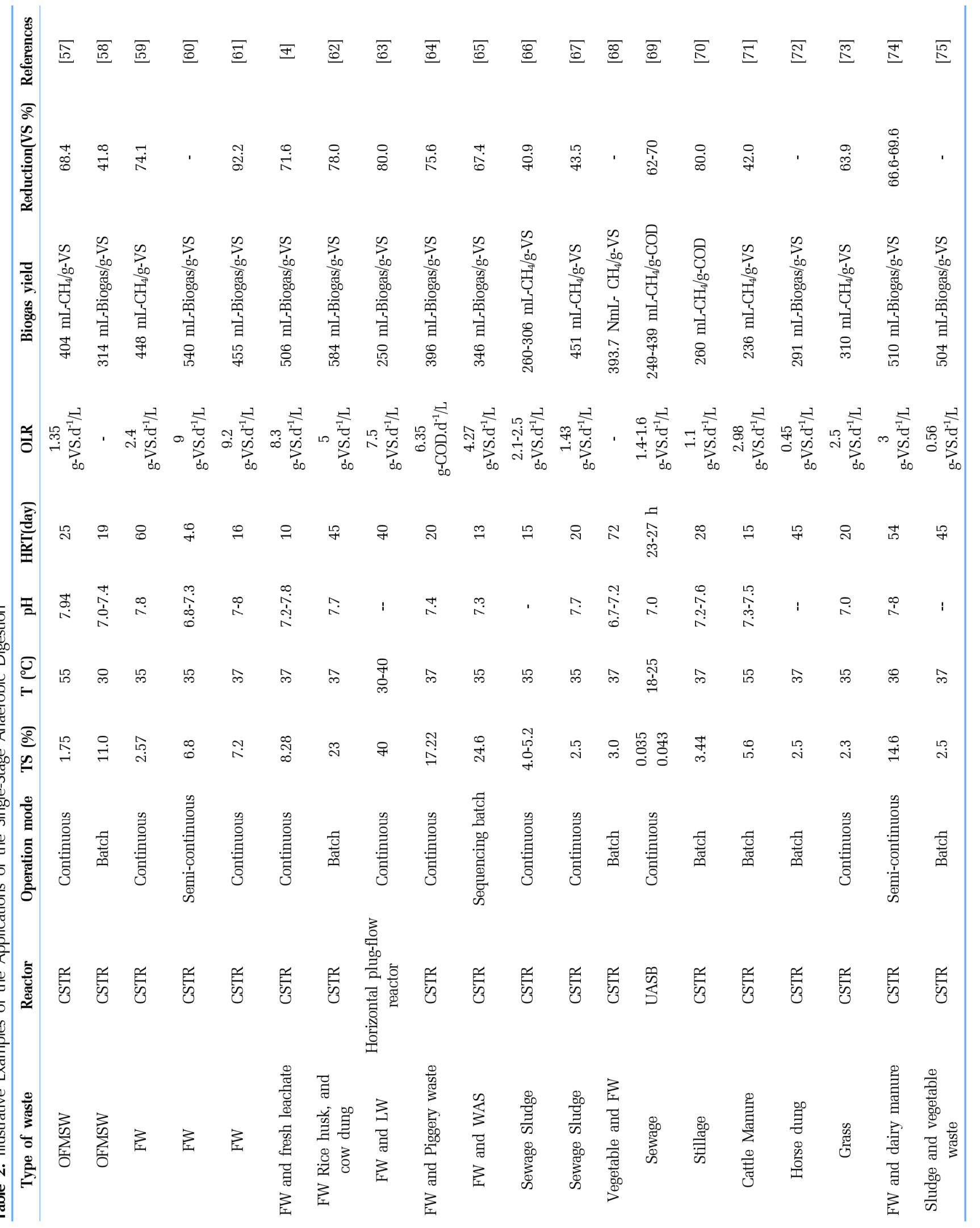




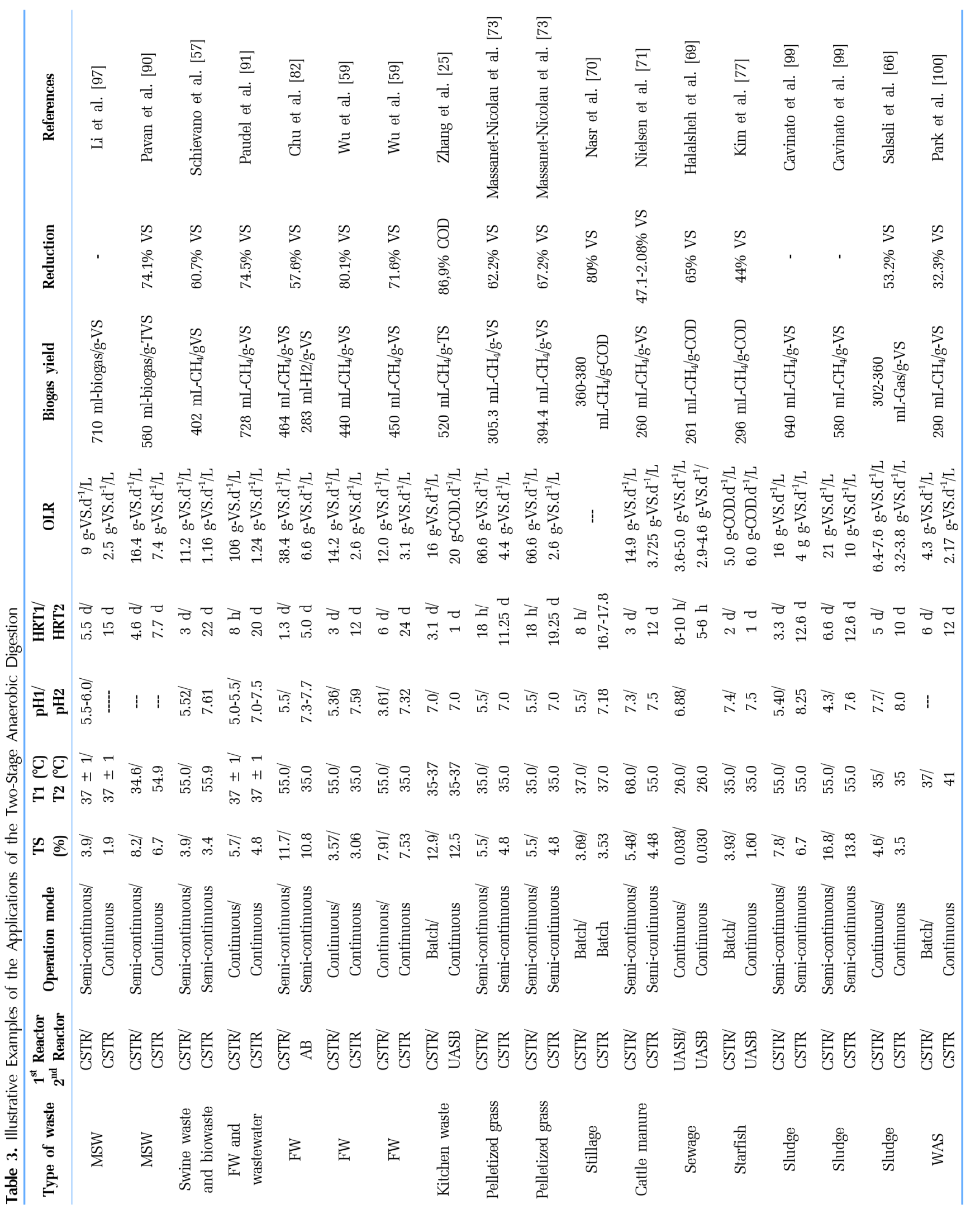


$\mathrm{RT}$ in the range of 1 to $3 \mathrm{~d}$ is preferred to use to deal with high-solid waste in the mesophilic condition [49, 54]. In case the reactor is operated in batch mode, RT should be maintained within 7-12 d [38].

Inhibitions: Despite strong and resilient characteristics the hydrolytic/acidogenic microorganism can still be inhibited by such high concentrations of organic acids (VFAs) and free ammonia. It has been reported that VFA up to $30 \mathrm{~g}-\mathrm{COD} / \mathrm{L}$ did not inhibit the hydrolysis process at neutral $\mathrm{pH}$ (6-7) [93], but VFA levels of 40-50 g-COD/L at low pHs (5.0-5.5) caused stopping the hydrolysis [94]. Koster and Lettinga [95] reported that acidogenesis were severely affected by ammonia concentration in the range of 4,051-5,734 mg $\mathrm{NH}_{3}-\mathrm{N} / \mathrm{L}$.

Nutrients: Deublein and Steinhauser [35] are two of the few authors who mentioned about nutrient demands for hydrolysis/acidogenesis and noted that $\mathrm{C} / \mathrm{N}$ ratio should be in the range of 10-40 while trace elements are not a special requirement.

\subsubsection{The methanogenic/acetogenesis reactor}

This phase often employs wet high-rate reactors such as CSTR, UASB, AFB, FB, EB, IC, and EGSB [14, 36]. These reactors have to be maintained with the methanogen-rich anaerobic environment which is obligate anaerobic and sensitive to the variation of temperature, $\mathrm{pH}$, and also RT [11, 15]. Therefore, operating conditions in the second reactor have to be complied strictly.

Solid concentrations: TS of the substrate coming to the methane reactor depends on the type of reactor employed. In case of using CSTR or CMR, TS of the substrate is allowed up to $10 \%$. Meanwhile, AFB reactor requires lower solid content of the influent (TS $\leq$ $5 \%$ ) [21, 55]. UASB, EB, FB, EGSB, and IC reactors even require lower solid content of the influent (TS $\leq 3 \%$ ) with biomass concentration inside be maintained in the range of $3.5-4 \%[21,36]$.

The pH value: As shown in Section 2.1, the optimal range of $\mathrm{pH}$ condition for methanogens and acetogens are very close to each other. Moreover, acetogens are stronger than methanogens. Therefore, optimizing $\mathrm{pH}$ condition for methanogens does not affect the growth of acetogens. In fact, $\mathrm{pH}$ in the range of 7.0-8.0 was often used (see Table 3). Moreover, this phase is an alkalinization process (converting acids to biogas), hence $\mathrm{pH}$ of the substrate to this reactor should be lower than the range above. Remarkably, when $\mathrm{pH}$ inside reactor drops below 6.5, the process should be stopped to adjust $\mathrm{pH}$ value.

Temperature: The optimal temperature for methanogenic bacteria under the mesophilic and thermophilic conditions are $35-37^{\circ} \mathrm{C}$ and $55^{\circ} \mathrm{C}$, respectively [15, 96]. Li et al. [97] and Pavan et al. [90] performed the digestion of MSW, used the same condition in hydrolysis but the different temperatures in methanogenesis. While at a temperature of $37^{\circ} \mathrm{C}$, Li et al. [97] had to operate the reactor with HRT $15 \mathrm{~d}$ to get $710 \mathrm{~mL}-\mathrm{CH}_{4} / \mathrm{g}-\mathrm{VS}$, at a higher temperature $\left(55^{\circ} \mathrm{C}\right)$ Pavan et al. [90] only needed to operate the reactor with HRT $12.5 \mathrm{~d}$ to get the same methane yield. In general, the biogas production rates under the thermophilic condition are sharply higher than those under mesophilic condition [15, 46]. Therefore, using thermophilic condition leads to increasing OLR and saving the construction cost significantly. However, thermophilic methanogens are more sensitive to environmental change than mesophilic anaerobes [15]. Thus, thermophilic reactor requires higher technology.

RT, OLR: Because of using the wet reactor then the term RT includes SRT and HRT. The SRT values greater than $20 \mathrm{~d}$ are needed for effective performance at the mesophilic condition, and it should be 7-15 $\mathrm{d}$ at the thermophilic temperature [36]. Meanwhile, HRT is shorter than SRT, varies from several h to nearly $20 \mathrm{~d}$ depending on the hydrolytic products, is often coupled with temperature and OLR values (see Table 3). Turovskiy and Mathai [54] recommended that HRT should be about $10 \mathrm{~d}$ at the mesophilic temperature for sludge treatment. Also at mesophilic temperature, Paudel et al. [91] optimized the methanogenic reactor with HRT $20 \mathrm{~d}$, ORL of $1.24 \mathrm{~g} \mathrm{VS} / \mathrm{L} / \mathrm{d}$ for co-digestion of FW and brown water. Rincón et al. [98] announced that 17 d was the best HRT with OLR of 9.2 g-COD/L/d when processing olive mill solid waste. To deal with MSW at mesophilic temperature, Li et al. [97] reported that OLR up to $3.8 \mathrm{~kg}-\mathrm{VS} / \mathrm{m}^{3} . \mathrm{d}^{-1}$ with HRT of $15 \mathrm{~d}$ resulted in biogas yield of $540 \mathrm{~mL} / \mathrm{g}-\mathrm{VS}$. Meanwhile, also for MSW but at the thermophilic condition, Pavan et al. [90] needed a shorter HRT (7.7 d) to get higher OLR (5.7 kg-VS $\left./ \mathrm{m}^{3} . \mathrm{d}^{-1}\right)$ with the same biogas yield. Also, Pavan et al. [90] recommended that HRT should be in the range of 8-9 $d$ to treat OFMSW at the thermophilic condition.

Nutrients and Inhibitions: It was often reported that the optimal $\mathrm{C}: \mathrm{N}: \mathrm{P}$ ratio in the range of 75-150:5:1 [36]. However, Lissens et al. [47] showed that methanogenic reactor run well with $\mathrm{C} / \mathrm{N}$ below 10. Methanogenic inhibition occurred when acetate concentration exceeded $3 \mathrm{~g} / \mathrm{L}$, even though there was sufficient alkalinity to maintain $\mathrm{pH}$ above 7.0 [36]. The optimum concentrations of sulfur for the growth of methanogens were reported in the literature to vary from 16 to $160 \mathrm{mg}-\mathrm{S} / \mathrm{L}$ [44]. Total ammonia of $3-7 \mathrm{~g} / \mathrm{L}$ may be tolerated in this reactor, but threshold values of FAN toxicity were reported to be in the range of 100-250 mg/L [36].

\subsubsection{Assessments}

The idea of the two-stage digestion not only optimizes each of hydrolysis/acidogenesis and methanogenesis to accelerate overall digestion progress but also brings many other advantages. The methanogens grow in their optimal environment, which leads to the fact that it is more difficult for them to be invaded by other groups compared to the single-stage digestion systems. Therefore, the two-stage digestion system is much more robust than the single-stage one and can run well with the fluctuation of the waste stream. Moreover, biogas produced from the hydrolysis/acidogenesis is not economical, can be removed out of the gas collection system easily without any more process. Thus, by this way, the costs of methane enrichment could be saved significantly. The recent results in applying the two-stage digestion systems are shown in Table 3. Most studies indicated that the two-stage system was better than the single-stage one because of shorter RTs or higher values of VS destruction [59, 66, 70, 71] (more details see Table 2 and Table 3). However, with the low solid contents in the feedstock (TS $<3 \%$ ), using the two-stage system does not bring more efficient than the single-stage system. For examples, Schievano et al. [57] used both single-stage and two-stage digestion systems to treat OFMSW at low TS condition (1.75-3.4\%) with the same conditions (HRT of $25 \mathrm{~d}$, temperature of $55^{\circ} \mathrm{C}$ ) and reported that the methane yield and VS destruction were observed almost the same in both 
systems. Halalsheh et al. [69] who experimented digestion of sewage with SS in the range of $350-430 \mathrm{mg} / \mathrm{L}$, also confirmed that the two-stage digestion system was not better than the single-stage.

\subsection{The Three-Stage Systems}

\subsubsection{Configuration of three-stage systems}

The second reactor of the two-stage digestion systems is responsible for both steps of acetogenesis and methanogenesis. Unfortunately, acetogens and methanogens have substantially different physiological properties and nutrient requirements. The growth balance between them can be lost by the environmental changes leading to severe inhibition [101]. Therefore, the idea of three-stage digestion has come out to separate the hydrolysis/acidogenesis, acetogenesis, and methanogenesis to various reactors [46, 101, 102].

However, as the reasons discussed in the previous section, the separation of both processes is not a good idea. From another viewpoint, Zhang et al. [103] and Stewart [22] proposed the three-stage digestion model with sequential steps: incomplete hydrolysis, hydrolysis/acidogenesis, and acetogenesis/methanogenesis. This proposal would increase the hydrolytic rate of feedstock in the first reactor significantly. Therefore, the second proposal is more valuable. In fact, due to non-homogeneous metabolism in reality then the distribution of digestion steps in three-stage digestion is, respectively hydrolysis/acidogenesis, acidogenesis/acetogenesis, and acetogenesis/methanogenesis. Hydrogen can be obtained in the first and second reactors, however, as being discussed in the previous section, the collection of hydrogen is not economical. Diagram of the three-stage digestion system is shown in Fig. 3.

Also, like the two-stage systems, the waste stream coming to the three-stage system has to undergo a mechanical pretreatment (particle size $<15 \mathrm{~mm}$ ), and water is sometimes added to the feedstock to adjust TS (max. 15\%). CSTR is still often used in the hydrolysis reactor. After hydrolysis, the non-hydrolysable materials are removed in the first buffer tank. Here, $\mathrm{pH}$ and VFAs concentration of the substrate can also be corrected for the next step. The second reactor operates such an anaerobic suspended growth process. Therefore, the second reactor is often a CSTR or UASB reactor. The effluent of the second reactor coming to the third one has to pass through a buffer tank as shown in Fig. 3 for purposes of controlling $\mathrm{pH}$, and concentration of acetic acid. Selections of the type of reactor, feeding mode, and temperature

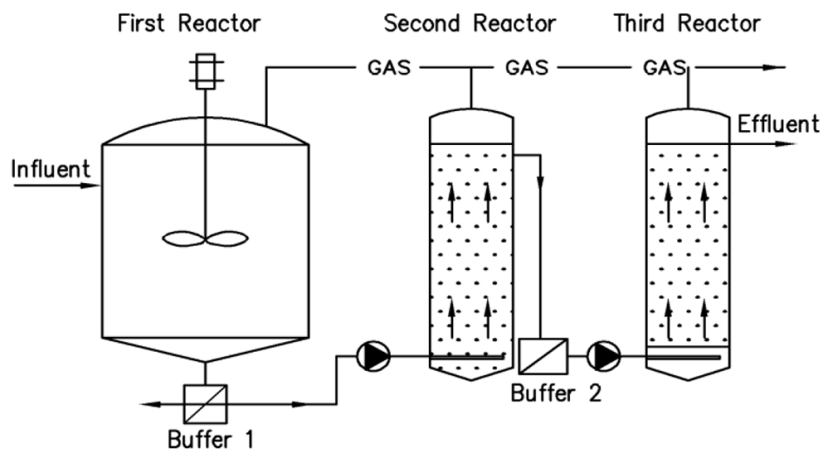

Fig. 3. Diagram of the three-stage anaerobic digestion system. phase for each digestion step make a complex matrix configuration of the three-stage digestion systems (see Table S3).

\subsubsection{Operations}

The first reactor: It is optimized for hydrolysis accompany with mechanical size reduction of the incoming feedstock. Biogas produced in this phase is mostly $\mathrm{CO}_{2}$. This reactor allows the prevailing acidic conditions to increase the rate of particle disruption and hydrolysis [25, 29]. Thus, the buffering agent is not often required in this reactor [22]. However, sometimes $\mathrm{pH}$ dropping below four leads to inhibiting hydrolysis immediately [80]. In fact, whether or not using a buffering agent depends on characteristics of the waste and the ways to operate the system. High temperature accelerates solubilization of the feedstock. He et al. [85] performed hydrolysis of food waste and reported that RT was three day to maximize COD-soluble concentration $(46.76 \mathrm{~g} / \mathrm{L})$ at $70^{\circ} \mathrm{C}$, but it took a longer time $(5 \mathrm{~d})$ at $55^{\circ} \mathrm{C}(43.33 \mathrm{~g} / \mathrm{L})$ and $35^{\circ} \mathrm{C}(36.25 \mathrm{~g} / \mathrm{L})$. However, mesophilic temperature $\left(30-35^{\circ} \mathrm{C}\right)$ is still often used along with RT of 2-3 d. Operation of this reactor could be referenced to the hydrolytic/acidogenic reactor discussed in the previous section. Also, the inhibitors in the feedstock can be retained in this reactor caused by absorption into sediment, and thus they reduce adverse impact on the next reactors [22].

The second reactor: It is optimized for acidogenesis and acetogenesis. Biogas produced in this phase mainly includes $\mathrm{CO}_{2}$ and $\mathrm{H}_{2}$ [22]. As shown in section 2.1, acidogenesis and acetogenesis thrive optimally in the $\mathrm{pH}$ condition in the range of 5.5-6.5 and 6.0-6.2, respectively. Therefore, the best condition for the second reactor is around $\mathrm{pH}$ 6.0. The mesophilic temperature $\left(35-37^{\circ} \mathrm{C}\right)$ is preferred to use in these processes with HRT of $2 \mathrm{~d}$ to deal with OFMSW (see Table 4). The completion of the second stage is marked by the conversion of almost VFAs into acetic acid.

The third reactor: The operation of this reactor is similar to the second reactor of two-stage digestion systems, such as optimum $\mathrm{pH}$ between 7.0 and 7.2 [18].

\subsubsection{Assessments}

As reported by Salsali et al. [66], three-stage digestion system had a higher performance of VS reduction and biogas yield compared to the two-stage system in the digestion of waste activated sludge. In fact, using three-stage digestion systems brings many disadvantages such as the high cost of investment, operations, and maintenance. Therefore, it is difficult to find out the application of the three-stage anaerobic digestion system for pilot scale. Pile [104] gave little information about the Inland Empire Regional Water Recycling Plant I, California, US. Before 2001, the plant had been operated as a single-stage system but not efficiently. Therefore, since 2001, the plant has been operated in separated-phases including the first reactor with HRT 2.5-3.5 d at $32-40^{\circ} \mathrm{C}$; the second reactor with HRT $18-20 \mathrm{~d}$ at $56-58^{\circ} \mathrm{C}$; and the third reactor with HRT $13-17 \mathrm{~d}$ at $42-48^{\circ} \mathrm{C}$. VS reduction has been improved from approximately 55\% to $60-65 \%$. However, from Tables 3 and 4, the three-stage systems did not produce more methane yield than the two-stage systems. The three-stage digestion is obviously a good idea for optimizing all digestion steps in principle, but it has not been proved persuasively to be better than the two-stage digestion system even in the lab scale. 


\begin{tabular}{|c|c|c|c|c|c|c|c|}
\hline 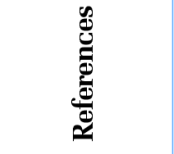 & $\stackrel{\text { 量 }}{=}$ & $\stackrel{\overline{\mathscr{g}}}{\varrho}$ & 蛋 & $\stackrel{\overline{8}}{\underline{E}}$ & 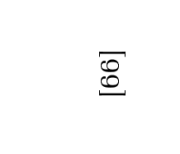 & $\stackrel{8}{0}$ & 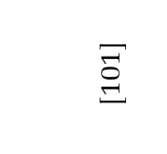 \\
\hline 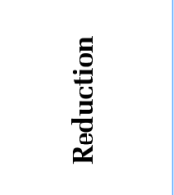 & $\begin{array}{l}\infty \\
\stackrel{\infty}{2} \\
\stackrel{0}{1}\end{array}$ & $\begin{array}{l}\infty \\
> \\
\infty \\
10 \\
\infty \\
\infty\end{array}$ & $\begin{array}{l}8 \\
0 \\
\circ \\
8 \\
8 \\
8\end{array}$ & 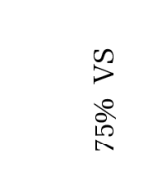 & 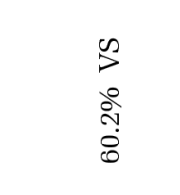 & $\begin{array}{l}\infty \\
1 \\
0 \\
0 \\
0 \\
10\end{array}$ & $\begin{array}{l}0 \\
8 \\
\circ \\
8 \\
8 \\
8\end{array}$ \\
\hline 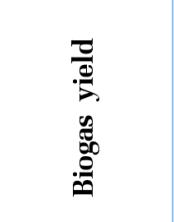 & 尽点 & 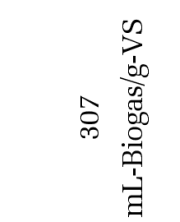 & 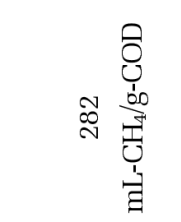 & 总 & 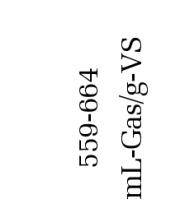 & 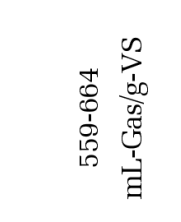 & 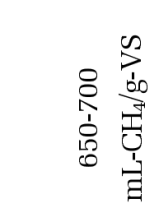 \\
\hline 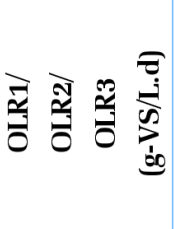 & 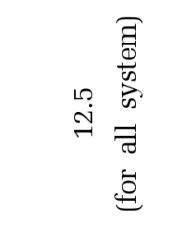 & 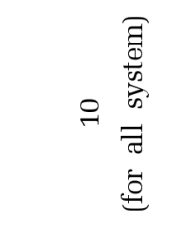 & 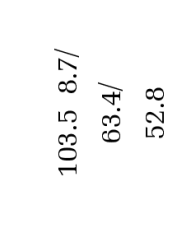 & 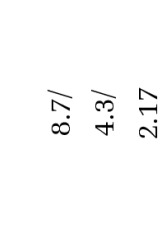 & 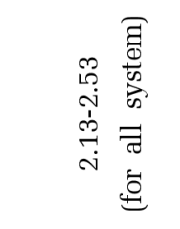 & 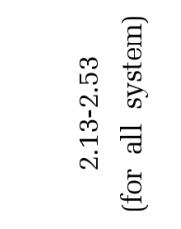 & 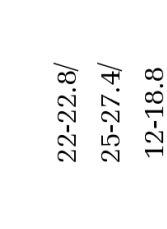 \\
\hline 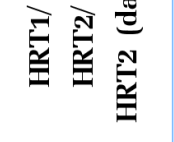 & $\vec{\partial} \vec{\partial}$ & $\underset{\vec{i}}{\vec{i}} \stackrel{\vec{i}}{ }$ ' & $\stackrel{\partial}{\vec{i}} \stackrel{\vec{i}}{i} \cong$ & $\begin{array}{l}\partial \vec{\partial} \vec{\partial} \bar{\jmath} \\
\dot{m}\end{array}$ & 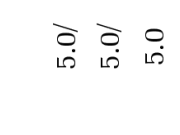 & 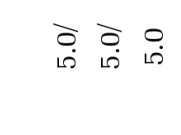 & $\underset{\mathrm{i}}{\vec{\partial}} \stackrel{a}{\mathrm{i}} \underset{\sim}{\sim}$ \\
\hline 高竞 & 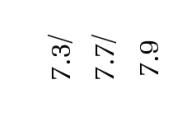 & 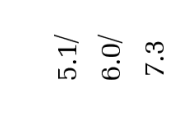 & 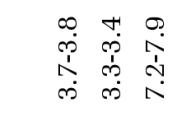 & $\underset{0}{\mathbb{0}} T$ & $\begin{array}{lll}\partial \overrightarrow{0} & \partial & 0 \\
\infty & \infty & 0 \\
& \infty & \infty\end{array}$ & $\begin{array}{lll}\partial \vec{c} & \bar{a} & 0 \\
\infty & \infty & 0 \\
\infty & \infty & \infty\end{array}$ & 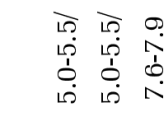 \\
\hline 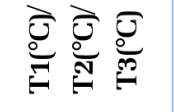 & 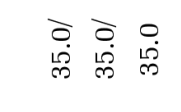 & 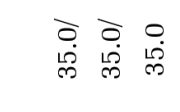 & 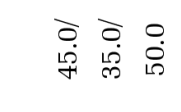 & 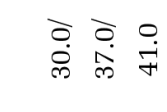 & 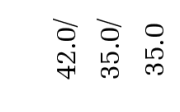 & 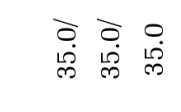 & 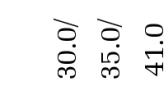 \\
\hline के के & 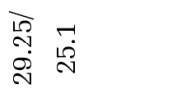 & 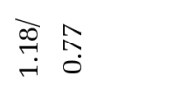 & 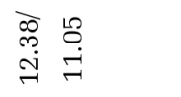 & $i \stackrel{\infty}{i}$ & ò & बे & 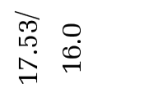 \\
\hline 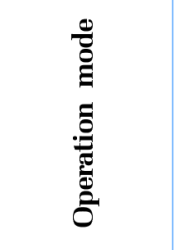 & 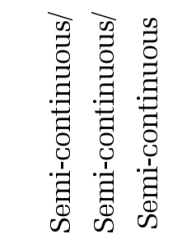 & 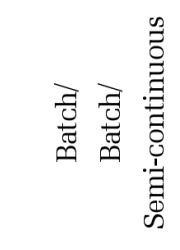 & 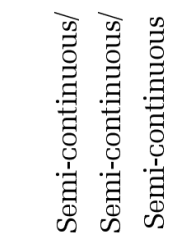 & 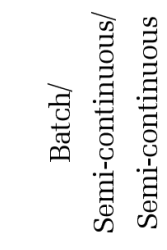 & 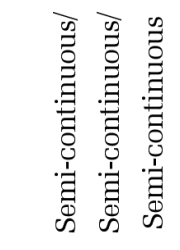 & 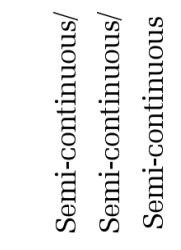 & 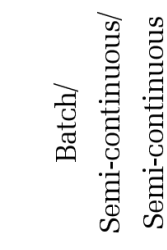 \\
\hline 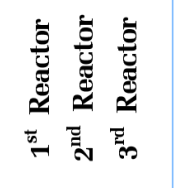 & 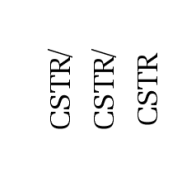 & 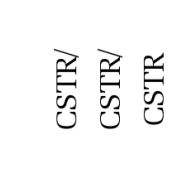 & 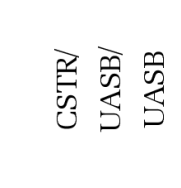 & 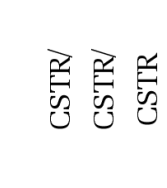 & 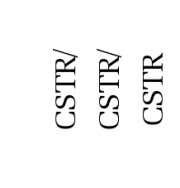 & 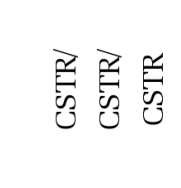 & 局商 \\
\hline 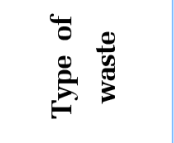 & 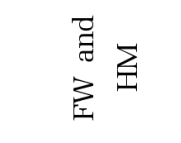 & 总 & $\overrightarrow{\vec{I}_{1}}$ & $\sum_{3}^{0}$ & $\sum_{3}^{n}$ & $\sum_{3}^{\infty}$ & 堂 \\
\hline
\end{tabular}




\section{Current Application}

The achievements of the $\mathrm{AD}$ not only solve the waste problems but also bring a new approach to energy production. For two recent decades, the total installed $\mathrm{AD}$ capacity has been increased five-fold worldwide from 2 million tons to 11 million tons a year [106]. Group of European countries has contributed the most proportion to the total biogas power generation with the increase of big biogas plants from 18 in 2001 to 418 in 2015 [10, 107]. In which, Germany has been a leader in using energy from biogas with a power capacity of 12,500 GWh by 2014 [10]. Beside European countries, the United States also contributes a significant proportion in using bio-waste for power generation with $181 \mathrm{AD}$ facilities processing OFMSW (total capacity of 780,000 tons/y, 2015) [108]. In contrast, although Japan is also a developed country with high potential of technologies, the application of biogas technologies is still slow: from one large biogas by $2004\left(150 \mathrm{Nm}^{3}\right.$-gas/h) up to six plants by 2009 (total 2,400 $\mathrm{Nm}^{3}$-gas/h) [107]. Meanwhile, for developing countries, low capacity digestion systems are commonly used that China is a typical example with the largest biogas program in the world. By the end of 2009, there had been over 30.5 million household biogas digesters (12.4 billion $\mathrm{m}^{3}$-gas/y) and 25,012 large-scale biogas projects (7,225 million $\mathrm{m}^{3}$-gas/y) $[10,109]$. Another smaller program, SNV (a Netherland Development Organization) supported the domestic biogas programs for 17 countries in Asia and Africa. By the end of 2012, SNV installed total 479,609 household digesters for Asian countries and 24,990 small digesters for African countries [110]. The biogas program in Nepal and Vietnam counted for over $80 \%$ of this total. In general, because of lacking technologies and the financial burden then the wet low rate digesters are commonly used in the developing countries with a large quantity but small-capacity (mainly household scale and farm scale). Meanwhile, the European countries with technical potential have advantage conditions to build large-scale plants which have much higher power capacity than China and other developing countries [5, 111], also see Fig. S3. So based on current installed capacity, the contribution of $\mathrm{AD}$ systems in the European can represent a panorama in applying $\mathrm{AD}$ systems over the world. Fig. 4 shows the current application of various $\mathrm{AD}$ systems in Europe by 2014.

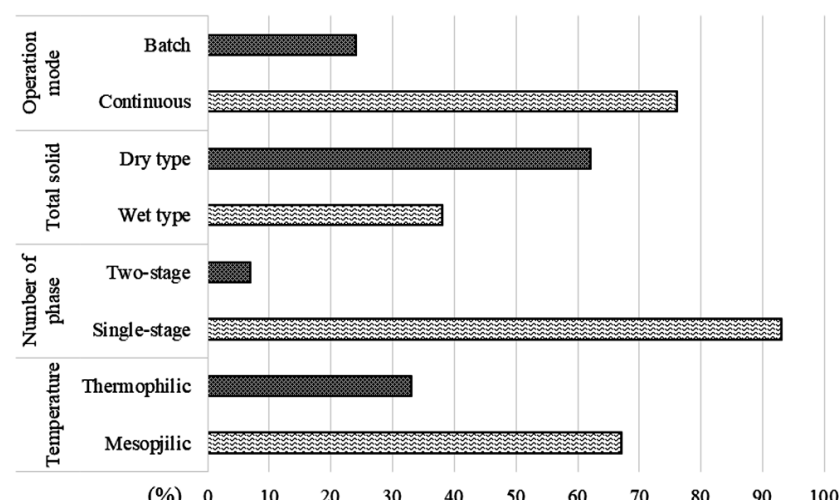

Fig. 4. Applications of $A D$ systems in Europe based on cumulative capacity installed in 2014 [111].
The discovering a significant increase of OLR in the thermophilic condition compared to the mesophilic condition has brought many advantages such as reducing the volume of the reactor in a new design and raising the capacity of the old reactor. Although the thermophilic technology requires a high stability of waste stream because of the sensitivity of the thermophilic bacteria, this is no longer an obstacle to the development of current technology. Thermophilic $\mathrm{AD}$ systems have only been studied and applied in recent years, it takes a long time to become popular. Thus, mesophilic $\mathrm{AD}$ systems are still more dominant in the present. The dry single-stage digestion systems are more stable, more robust, have a smaller reactor, and produce less residual wastewater than the wet systems. It has been most applied in Europe to deal with OFMSW which accounts for the highest proportion of the biodegradable waste sectors. Thus, based on cumulative installed capacity, the dry single-stage digestion systems are still overwhelming applicated as shown in Fig. 4. The batch process often accompanies with disadvantages such as variable biogas production following time, long HRT, big reactor, and uncompleted degradation. However, it brings many advantages including simple material handling, less pre-processing requirements, easily controlling, and especially easy separation of hydrolysis and methanogenesis. Therefore, the batch process which has been soon being applied since 2009 for digestion of OFMSW, is estimated continuously to increase in use due to their simplicity and low cost $[5,111]$. It is easy to understand the lack of three-stage system in Fig. 4 because the three-stage system has not been proved to have more methane yield than the two-stage system meanwhile it is much more complex in operating and also consumes higher energy.

\section{Conclusions and Recommendations}

The single-stage wet low-rate digestion systems are characterized by producing low biogas yield and low OLR $\left(0.5-1.6 \mathrm{~kg}-\mathrm{VS} / \mathrm{m}^{3} \cdot \mathrm{d}^{-1}\right)$, requiring long RT (30-60 d) of the feedstock and big reactors, and depending on the outdoor temperature during the operation. However, they bring many advantages such as easy operation and cheap investment. In perspective economic benefits, they should only be applied for fine biodegradable waste sources (such as animal manures) without requiring any pretreatment step. Therefore, the wet low-rate system is a good solution for warm-climate rural areas, where agricultural land is available, and digestive products can turn back to serve for agricultural activities.

The single-stage wet high-rate digestion systems are much more effective than the wet low-rate systems with OLR up to 4-8 $\mathrm{kg}-\mathrm{VS} / \mathrm{m}^{3} \cdot \mathrm{d}^{-1}$. However, the operation is more complex than the low-rate one because of the attached equipment and pre-treatment process sometimes. The feedstock with low solid contents $(<3-5 \%)$ is the best source for these systems with many selections of reactors such as UASB, FBR, EBR, EGBR, and CSTR. When TS > 5\%, the CSTR is often used. In fact, these systems have been applied widely to deal with sewage sludge, agricultural products, and industrial wastewater. They can also be used to treat high solid feedstock (TS $>20 \%$ ) such as OFMSW, but it requires to be diluted. At that time, water consumption and energy expense significantly 
reduce the energy benefit of the system.

The single-stage dry digestion systems have brought a milestone for the $\mathrm{AD}$ technology, which can deal with high solid feedstock (TS $=30-35 \%$ ) and high OLR (up to $15 \mathrm{~kg}-\mathrm{VS} / \mathrm{m}^{3} \cdot \mathrm{d}^{-1}$ ). In case of too high solid contents in the feedstock ( $>35 \%$ ), it should be diluted. They are very suitable for handling OFMSW which accounts for a large amount of biodegradable waste sector. These systems can be distinguished by continuous operation mode or batch operation mode. For continuous mode, there are many advantages attached such as low water consumption, small reactor, very little wastewater production, cheap pre-treatment, waste residue well applied for composting, and less heat requirement. Thus, the continuous mode systems should be applied for urban areas. For batch mode systems, it costs lower for equipment invest and operation. However, it needs much larger space than the continuous mode systems and gas generation is variable. Therefore, the batch mode systems is a great solution for suburban areas.

The two-stage $\mathrm{AD}$ systems with separation of hydrolysis and methanogenesis in various reactors could have shorter HRT and higher OLR (up to $50 \mathrm{~kg}-\mathrm{COD} / \mathrm{m}^{3} / \mathrm{d}$ ) than the single-stage systems. They bring many advantages such as lower construction cost, much more operational flexibility, more robust, highest methane content, higher digestion efficiency, and especially well running with low $\mathrm{C} / \mathrm{N}(<10)$. The best application range for solid content of the feedstock is in the range of $5-15 \%$. When TS $<5 \%$, using the single-stage wet systems might better. When TS $>20 \%$, the dilution of the waste stream causes a significant increase in energy needed for heating, pumping and expanding reactors, hence it is better to use the dry single-stage digestion system. The two-stage $\mathrm{AD}$ systems are suitable to deal with industrial wastewater.

The performance of the three-stage digestion systems has not been improved compared to the two-stage systems. Moreover, because it has more complex operation, more expensive investment, more energy for maintenance and operation compared to two-stage $\mathrm{AD}$ systems, application of the three-stage system for large scale is not a good selection at present. However, three-stage systems are still a good idea; its operation should be studied further to reduce the cost involved.

\section{Ackowledgments}

The authors would like to acknowledge the Graduate School of Environmental and Life Science (Okayama Univ., Japan) for their financial support.

\section{References}

1. Hoornweg D, Bhada-Tata P. What a waste: A global review of solid waste management. In: Urban development series knowledge papers, vol.15; Washington D.C.: World bank; 2012.

2. Al Seadi T, Owen N, Hellström H, Kang H. Source separation of MSW. In: IEA Bioenergy. The International Energy Agency; 2013.

3. Trzcinski AP, David CS. Microbial biomethane from solid wastes: Principles and biotechnogical processes. In: Harzevili
FD, Hiligsmann S, eds. Microbial fuels. USA: CRC Press; 2017. p. 77-151.

4. Zhang W, Zhang L, Li A. Anaerobic co-digestion of food waste with MSW incineration plant fresh leachate: Process performance and synergistic effects. Chem. Eng. J. 2015;259:795-805.

5. Rapport J, Zhang R, Jenkins BM, Williams RB. Current anaerobic digestion technologies used for treatment of municipal organic solid waste. In: California Environmental Protection Agency. California: California Integrated Waste Management Board; 2008.

6. Kothari R, Pandey A, Kumar S, Tyagi V, Tyagi S. Different aspects of dry anaerobic digestion for bio-energy: An overview. Renew. Sust. Energ. Rev. 2014;39:174-195.

7. Kayhanian M, Tchobanoglous G, Brown RC. Biomass conversion processes for energy recovery. In: Kreith F, Goswami DY, eds. Handbook of energy efficiency and renewable energy. Florida: CRC Press; 2007. p. 22.1-22.67.

8. Han D, Tong X, Currell MJ, Cao G, Jin M, Tong C. Evaluation of the impact of an uncontrolled landfill on surrounding groundwater quality, Zhoukou, China. J. Geochem. Explor. 2014;136: 24-39.

9. Chen HH, Lee AH. Comprehensive overview of renewable energy development in Taiwan. Renew. Sust. Energ. Rev. 2014;37:215-228.

10. Deng Y, Xu J, Liu Y, Mancl K. Biogas as a sustainable energy source in China: Regional development strategy application and decision making. Renew. Sust. Energ. Rev. 2014;35:294-303.

11. Mao C, Feng Y, Wang X, Ren G. Review on research achievements of biogas from anaerobic digestion. Renew. Sust. Energ. Rev. 2015;45:540-555.

12. Chiu S, Lo I. Reviewing the anaerobic digestion and co-digestion process of food waste from the perspectives on biogas production performance and environmental impacts. Environ. Sci. Pollut. Res. 2016;23:24435-24450.

13. Zhang C, Su H, Baeyens J, Tan T. Reviewing the anaerobic digestion of food waste for biogas production. Renew. Sust. Energ. Rev. 2014;38:383-392.

14. Chernicharo L, Augusto C. Anaerobic reactors. In: Biological Wastewater Treatment Series, London: IWA publishing; 2007.

15. Gerardi $\mathrm{MH}$. The microbiology of anaerobic digesters. In: Wastewater Microbiology Series. New Jersey: Wiley-Interscience; 2003.

16. Demirel B, Yenigün O. Two-phase anaerobic digestion processes: A review. J. Chem. Technol. Biotechnol. 2002;77:743-755.

17. Appels L, Baeyens J, Degrève J, Dewil R. Principles and potential of the anaerobic digestion of waste-activated sludge. Prog. Energ. Combust. Sci. 2008;34:755-781.

18. Ostrem K. Greening waste: Anaerobic digestion for treating the organic fraction of municipal solid wastes [dissertation]. New York: Columbia Univ.; 2004.

19. Ziemiński K, Frąc M. Methane fermentation process as anaerobic digestion of biomass: Transformations, stages and microorganisms. Afr. J. Biotechnol. 2012;11:4127-4139.

20. Demirel B, Scherer P. The roles of acetotrophic and hydrogenotrophic methanogens during anaerobic conversion of biomass to methane: A review. Rev. Environ. Sci. Biotechnol. 2008;7:173-190.

21. Abbasi T, Tauseef S, Abbasi SA. Biogas energy. In: Springer 
Briefs in Environmental Science. New York: Springer Science and Business Media; 2011.

22. Stewart WC. Three stage, multiple phase anaerobic digestion system and method [Internet]. Google Patents; c2014. Available from: https://patents.google.com/patent/US5500123.

23. Zhang P, Chen Y, Zhou Q. Waste activated sludge hydrolysis and short-chain fatty acids accumulation under mesophilic and thermophilic conditions: Effect of $\mathrm{pH}$. Water Res. 2009;43:3735-3742.

24. Sanders WTM. Anaerobic hydrolysis during digestion of complex substrates [dissertation]. Netherlands: Wageningen Univ.; 2001.

25. Zhang B, Zhang L, Zhang S, Shi H, Cai W. The influence of $\mathrm{pH}$ on hydrolysis and acidogenesis of kitchen wastes in two-phase anaerobic digestion. Environ. Technol. 2005;26: 329-340.

26. Krishna D, Kalamdhad AS. Pre-treatment and anaerobic digestion of food waste for high rate methane production - A review. J. Environ. Chem. Eng. 2014;2:1821-1830.

27. Ariunbaatar J, Panico A, Esposito G, Pirozzi F, Lens PN. Pretreatment methods to enhance anaerobic digestion of organic solid waste. Appl. Energ. 2014;123:143-156.

28. Buyukkamaci N, Filibeli A. Volatile fatty acid formation in an anaerobic hybrid reactor. Process Biochem. 2004;39: 1491-1494.

29. Cysneiros D, Banks CJ, Heaven S, Karatzas KAG. The effect of $\mathrm{pH}$ control and 'hydraulic flush' on hydrolysis and Volatile Fatty Acids (VFA) production and profile in anaerobic leach bed reactors digesting a high solids content substrate. Bioresour. Technol. 2012;123:263-271.

30. Pham TN, Nam WJ, Jeon YJ, Yoon HH. Volatile fatty acids production from marine macroalgae by anaerobic fermentation. Bioresour. Technol. 2012;124:500-503.

31. Ramos-Suárez J, Arroyo NC, González-Fernández C. The role of anaerobic digestion in algal biorefineries: Clean energy production, organic waste treatment, and nutrient loop closure. In: Singh B, Kuldeep B, Faizal B, eds. Algae and environmental sustainability. India: Springer; 2015. p. 53-76.

32. Horiuchi J, Shimizu T, Kanno T, Kobayashi M. Dynamic behavior in response to $\mathrm{pH}$ shift during anaerobic acidogenesis with a chemostat culture. Biotechnol. Tech. 1999;13:155-157.

33. Fang HH, Liu H. Effect of $\mathrm{pH}$ on hydrogen production from glucose by a mixed culture. Bioresour. Technol. 2002;82:87-93.

34. Stronach SM, Rudd T, Lester JN. Anaerobic digestion processes in industrial wastewater treatment. In: Aiba S, Fan LT, Fiechter A, de Klein J, Schügerl K, eds. Biotechnology monographs. Berlin, Germany: Springer Science and Business Media; 2012.

35. Deublein D, Steinhauser A. Biogas from waste and renewable resources: An introduction. Germany: Wiley-Interscience; 2011.

36. Burton FL, Stensel HD, Tchobanoglous G. Wastewater engineering: Treatment and resource recovery. 5th ed. New York: McGraw-Hill; 2014.

37. van Lier JB, Mahmoud N, Zeeman G. Anaerobic wastewater treatment. In: Henze M, van Loosdrecht M, Ekama G, Brdjanovic D, eds. Biological wastewater treatment: Principles, modelling and design. London, UK: IWA Publishing; 2008. p. 415-456.
38. Yu L, Ma J, Frear C, Zaher U, Chen S. Two-stage anaerobic digestion systems wherein one of the stages comprises a two-phase system. Google patents. 2013.

39. Nayono SE. Anaerobic digestion of organic solid waste for energy production [dissertation]. Germany: Karlsruhe Institute of Technology; 2010.

40. Gallert C, Winter J. Mesophilic and thermophilic anaerobic digestion of source-sorted organic wastes: Effect of ammonia on glucose degradation and methane production. Appl. Microbiol. Biotechnol. 1997;48:405-410.

41. Duan N, Dong B, Wu B, Dai X. High-solid anaerobic digestion of sewage sludge under mesophilic conditions: Feasibility study. Bioresour. Technol. 2012;104:150-156.

42. Nakakubo R, Møller HB, Nielsen AM, Matsuda J. Ammonia inhibition of methanogenesis and identification of process indicators during anaerobic digestion. Environ. Eng. Sci. 2008;25:1487-1496.

43. Yenigün O, Demirel B. Ammonia inhibition in anaerobic digestion: A review. Process Biochem. 2013;48:901-911.

44. Uemura S. Mineral requirements for mesophilic and thermophilic anaerobic digestion of organic solid waste. Int. J. Environ Res. 2010;4:33-40.

45. El-Mashad HM, Zeeman G, van Loon WKP, Bot GPA, Lettinga G. Effect of temperature and temperature fluctuation on thermophilic anaerobic digestion of cattle manure. Bioresour. Technol. 2004;95:191-201.

46. Kim JK, Oh BR, Chun YN, Kim SW. Effects of temperature and hydraulic retention time on anaerobic digestion of food waste. J. Biosci. Bioeng. 2006;102:328-332.

47. Lissens G, Vandevivere P, De Baere L, Biey E, Verstraete W. Solid waste digestors: Process performance and practice for municipal solid waste digestion. Water Sci. Technol. 2001;44: 91-102.

48. Angelonidi E, Smith SR. A comparison of wet and dry anaerobic digestion processes for the treatment of municipal solid waste and food waste. Water Environ. J. 2015;29:549-557.

49. Vandevivere P, De Baere L, Verstraete W. Types of anaerobic digester for solid wastes. In: Mata-Alvarez J, ed. Biomethanization of the organic fraction of municipal solid wastes. London: IWA Publishing; 2003. p. 111-140.

50. Pandey A. Solid-state fermentation. Biochem. Eng. J. 2003;13: 81-84.

51. Behrens M, Peuckert J, Meeusen M. Review on standards for biogasification. Opening bio-based markets via standards, labelling and procurement 2014, IEEE: Gent, Belgium.

52. Tchobanoglous G, Burton FL, Stensel HD, Metcalf \& Eddy. Wastewater engineering: Treatment and reuse. New York McGraw-Hill Education; 2003.

53. Yen HW, Brune DE. Anaerobic co-digestion of algal sludge and waste paper to produce methane. Bioresour. Technol. 2007;98:130-134.

54. Turovskiy IS, Mathai P. Wastewater sludge processing. New Jersey: Wiley-Interscience; 2006.

55. Roos K, Martin J, Moser M. AgSTAR handbook: A manual for developing biogas systems at commercial farms in the United States. US EPA; 2004.

56. D'Addario E, Pappa R, Pietrangeli B, Valdiserri M. The acido- 
genic digestion of the organic fraction of municipal solid waste for the production of liquid fuels. Water Sci. Technol. 1993;27:183-192.

57. Schievano A, Tenca A, Scaglia B, et al. Two-stage vs. single-stage thermophilic anaerobic digestion: Comparison of energy production and biodegradation efficiencies. Environ. Sci. Technol. 2012;46:8502-8510.

58. Dong L, Zhenhong Y, Yongming S. Semi-dry mesophilic anaerobic digestion of water sorted organic fraction of municipal solid waste (WS-OFMSW). Bioresour. Technol. 2010;101: 2722-2728.

59. Wu LJ, Kobayashi T, Li YY, Xu KQ. Comparison of single-stage and temperature-phased two-stage anaerobic digestion of oily food waste. Energy Convers. Manage. 2015;106:1174-1182.

60. Zhang C, Su H, Tan T. Batch and semi-continuous anaerobic digestion of food waste in a dual solid-liquid system. Bioresour. Technol. 2013;145:10-16.

61. Nagao N, Tajima N, Kawai M, et al. Maximum organic loading rate for the single-stage wet anaerobic digestion of food waste. Bioresour. Technol. 2012;118:210-218.

62. Haider MR, Zeshan, Yousaf S, Malik RN, Visvanathan C. Effect of mixing ratio of food waste and rice husk co-digestion and substrate to inoculum ratio on biogas production. Bioresour. Technol. 2015;190:451-457.

63. Kim DH, Oh SE. Continuous high-solids anaerobic co-digestion of organic solid wastes under mesophilic conditions. Waste Manage. 2011;31:1943-1948.

64. Zhang L, Lee YW, Jahng D. Anaerobic co-digestion of food waste and piggery wastewater: Focusing on the role of trace elements. Bioresour. Technol. 2011;102:5048-5059.

65. Heo NH, Park SC, Kang H. Effects of mixture ratio and hydraulic retention time on single-stage anaerobic co-digestion of food waste and waste activated sludge. J. Environ. Sci. Health Part A. 2004;39:1739-1756.

66. Salsali H, Parker W, Sattar S. Influence of staged operation of mesophilic anaerobic digestion on microbial reduction. Proc. Water Environ. Fed. 2005;51-60:4571-4586.

67. Song YC, Kwon SJ, Woo JH. Mesophilic and thermophilic temperature co-phase anaerobic digestion compared with single-stage mesophilic-and thermophilic digestion of sewage sludge. Water Res. 2004;38:1653-1662.

68. Pham Van D, Hoang MG, Pham Phu ST, Fujiwara T. Kinetics of carbon dioxide, methane and hydrolysis in co-digestion of food and vegetable wastes. Global J. Environ. Sci. Manage. 2018;4:401-412.

69. Halalsheh M, Sawajneh Z, Zu'bi M, et al. Treatment of strong domestic sewage in a $96 \mathrm{~m} 3$ UASB reactor operated at ambient temperatures: Two-stage versus single-stage reactor. Bioresour. Technol. 2005;96:577-585.

70. Nasr N, Elbeshbishy E, Hafez H, Nakhla G, El Naggar MH. Comparative assessment of single-stage and two-stage anaerobic digestion for the treatment of thin stillage. Bioresour. Technol. 2012;111:122-126.

71. Nielsen H, Mladenovska Z, Westermann P, Ahring BK. Comparison of two-stage thermophilic $\left(68^{\circ} \mathrm{C} / 55^{\circ} \mathrm{C}\right)$ anaerobic digestion with one-stage thermophilic $\left(55^{\circ} \mathrm{C}\right)$ digestion of cattle manure. Biotechnol. Bioeng. 2004;86:291-300.
72. Pham Van D, Hoang MG, Pham Phu ST, Fujiwara T. A new kinetic model for biogas production from co-digestion by batch mode. Global J. Environ. Sci. Manage. 2018;4:251-262.

73. Massanet-Nicolau J, Dinsdale R, Guwy A, Shipley G. Utilising biohydrogen to increase methane production, energy yields and process efficiency via two stage anaerobic digestion of grass. Bioresour. Technol. 2015;189:379-383.

74. Agyeman FO, Tao W. Anaerobic co-digestion of food waste and dairy manure: Effects of food waste particle size and organic loading rate. J. Environ. Manage. 2014;133:268-274.

75. Dinh PV, Fujiwara T, Pham Phu ST, Giang HM. Kinetic of biogas production in co-digestion of vegetable waste, horse dung, and sludge by batch reactors. In: 4th International Conference on Environment and Renewable Energy (ICERE); June 2014; Da Nang.

76. Aslanzadeh S, Rajendran K, Jeihanipour A, Taherzadeh MJ. The effect of effluent recirculation in a semi-continuous two-stage anaerobic digestion system. Energies 2013;6:2966-2981.

77. Kim DH, Cha J, Lee MK, Kim HW, Kim MS. Prediction of bio-methane potential and two-stage anaerobic digestion of starfish. Bioresour. Technol. 2013;141:184-190.

78. Rosgaard L, Andric P, Dam-Johansen K, Pedersen S, Meyer AS. Effects of substrate loading on enzymatic hydrolysis and viscosity of pretreated barley straw. Appl. Biochem. Biotechnol. 2007;143:27-40.

79. Kristensen JB, Felby C, Jørgensen H. Yield-determining factors in high-solids enzymatic hydrolysis of lignocellulose. Biotechnol. Biofuels 2009;2:1-10.

80. Moestedt J, Nordell E, Hallin S, Schnürer A. Two-stage anaerobic digestion for reduced hydrogen sulphide production. J. Chem. Technol. Biotechnol. 2016;91:1055-1062.

81. Yu HQ, Fang HHP. Acidogenesis of dairy wastewater at various pH levels. Water Sci. Technol. 2002;45:201-206.

82. Chu CF, Li YY, Xu KQ, Ebie Y, Inamori Y, Kong HN. A pHand temperature-phased two-stage process for hydrogen and methane production from food waste. Int. J. Hydrogen Energ. 2008;33:4739-4746.

83. Jiang J, Zhang Y, Li K, Wang Q, Gong C, Li M. Volatile fatty acids production from food waste: Effects of $\mathrm{pH}$, temperature, and organic loading rate. Bioresour. Technol. 2013;143:525-530.

84. Lindner J, Zielonka S, Oechsner H, Lemmer A. Effect of different $\mathrm{pH}$-values on process parameters in two-phase anaerobic digestion of high-solid substrates. Environ. Technol. 2015;36:198-207.

85. He M, Sun Y, Zou D, et al. Influence of temperature on hydrolysis acidification of food waste. Procedia Environ. Sci. 2012;16:85-94.

86. Mata-Alvarez J. Biomethanization of the organic fraction of municipal solid wastes. Fundamentals of the anaerobic digestion process. London, UK: IWA publishing; 2003.

87. Kim M, Gomec CY, Ahn Y, Speece R. Hydrolysis and acidogenesis of particulate organic material in mesophilic and thermophilic anaerobic digestion. Environ. Technol. 2003;24: 1183-1190.

88. Kozuchowska J, Evison LM. VFA production in pre-acidification systems without $\mathrm{pH}$ control. Environ. Technol. 1995;16:667-675.

89. Komemoto K, Lim YG, Nagao N, Onoue Y, Niwa C, Toda T. 
Effect of temperature on VFA's and biogas production in anaerobic solubilization of food waste. Waste Manage. 2009;29: 2950-2955.

90. Pavan P, Battistoni P, Cecchi F, Mata-Alvarez J. Two-phase anaerobic digestion of source sorted OFMSW (organic fraction of municipal solid waste): Performance and kinetic study. Water Sci. Technol. 2000;41:111-118.

91. Paudel S, Kang Y, Yoo YS, Seo GT. Effect of volumetric organic loading rate (OLR) on $\mathrm{H}_{2}$ and $\mathrm{CH}_{4}$ production by two-stage anaerobic co-digestion of food waste and brown water. Waste Manage. 2017;61:484-493.

92. Dareioti MA, Kornaros M. Effect of hydraulic retention time (HRT) on the anaerobic co-digestion of agro-industrial wastes in a two-stage CSTR system. Bioresour. Technol. 2014;167: 407-415.

93. Veeken A, Kalyuzhnyi S, Scharff H, Hamelers B. Effect of $\mathrm{pH}$ and VFA on hydrolysis of organic solid waste. J. Environ. Eng. 2000;126:1076-1081.

94. Veeken AHM, Hamelers BVM. Effect of substrate-seed mixing and leachate recirculation on solid state digestion of biowaste. Water Sci. Technol. 2000;41:255-262.

95. Koster IW, Lettinga G. Anaerobic digestion at extreme ammonia concentrations. Biol. Wastes 1988;25:51-59.

96. Zhang J, Sun K, Wu M, Zhang L. Influence of temperature on performance of anaerobic digestion of municipal solid waste. J. Environ. Sci. 2006;18:810-815.

97. Li W, Guo J, Cheng H, Wang W, Dong R. Two-phase anaerobic digestion of municipal solid wastes enhanced by hydrothermal pretreatment: Viability, performance and microbial community evaluation. Appl. Energy 2017;189:613-622.

98. Rincón B, Borja R, González JM, Portillo MC, Sáiz-Jiménez C. Influence of organic loading rate and hydraulic retention time on the performance, stability and microbial communities of one-stage anaerobic digestion of two-phase olive mill solid residue. Biochem. Energ. J. 2008;40:253-261.

99. Cavinato C, Bolzonella D, Fatone F, Cecchi F, Pavan P. Optimization of two-phase thermophilic anaerobic digestion of biowaste for hydrogen and methane production through reject water recirculation. Bioresour. Technol. 2011;102: 8605-8611.

100. Park C, Lee C, Kim S, Chen Y, Chase HA. Upgrading of anaerobic digestion by incorporating two different hydrolysis processes. J. Biosci. Bioeng. 2005;100:164-167.

101. Kim SW, Park JY, Kim JK, et al. Development of a modified three-stage methane production process using food wastes. Appl. Biochem. Biotechnol. 2000;84:731-741.

102. Kim JK, Han GH, Oh BR, Chun YN, Eom CY, Kim SW. Volumetric scale-up of a three stage fermentation system for food waste treatment. Bioresour. Technol. 2008;99:4394-4399.

103. Zhang J, Loh K-C, Li W, Lim JW, Dai Y, Tong YW. Three-stage anaerobic digester for food waste. Appl. Energ. 2016;194: 287-295.

104. Pile A. Biosolids technology fact sheet: Multi-stage anaerobic digestion. EPA USA; 2006. p. 2010.

105. Zhang J, Loh KC, Lee J, Wang CH, Dai Y, Tong YW. Three-stage anaerobic co-digestion of food waste and horse manure. Sci. Rep. 2017;7:1269.

106. Arsova L. Anaerobic digestion of food waste: Current status, problems and an alternative product [dissertation]. New York: Columbia Univ.; 2010.

107. IEA Bioenergy. Energy from biogas task 37 plant list 2015 [Internet]. Available from: http://task37.ieabioenergy.com/ plant-list.html.

108. Ergas SJ, Yeh DH, Hinds GR, Wang M, Dick G. Bioenergy production from MSW by solid-state anaerobic digestion [dissertation]. Florida: Univ. of South Florida; 2017.

109. Jiang X, Sommer SG, Christensen KV. A review of the biogas industry in China. Energy Policy 2011;39:6073-6081.

110. Surendra K, Takara D, Hashimoto AG, Khanal SK. Biogas as a sustainable energy source for developing countries: Opportunities and challenges. Renew. Sust. Energ. Rev. 2014;31:846-859.

111. De Baere L, Mattheeuws B. Anaerobic digestion of the organic fraction of municipal solid waste in Europe-Status, experience and prospects. In: Waste management: Recycling and recovery. January 2012. p. 517-526. 